\title{
THE EMERGENCE OF THE INTERGOVERMENTAL TRUST IN INTERNATIONAL LAW
}

\author{
Ilias Bantekas*
}

\section{Introduction}

Intergovernmental trusts, or trust funds, have been around for a few decades, grounded on a proliferation of international agreements. Yet, surprisingly, none of these agreements, nor the institutional law of international organisations acting as trustees thereto, have attempted even once to set out the legal nature of these arrangements. The relevant protagonists are content to simply establish them by means of agreement on the basis of certain underlying assumptions that are taken for granted. State practice is in fact so consistent and uniform in respect of these underlying assumptions, despite the absence of formal definitions, that a claim of customary international law would be well justified; this potential for a customary nature is amply debated on the basis of the consistent practice of States in respect of trust agreements, albeit only with regard to particular characteristics. The absence of definitions by the two main actors in the trust relationship, i.e., donors and trustees, is hardly conspicuous, given that it avoids limiting and restrictively delineating the range of operations and relationships encompassed within the trust paradigm. In this manner, one is in the dark as to whether the trust relationship is governed by the international law of agency, or whether it constitutes a sui generis arrangement that lacks agency qualities altogether. Equally, if indeed of a sui generis nature, it is uncertain whether the general law of privileges and immunities applies to trusts that are not also international organisations and whether the donors owe extracontractual duties to third parties. Nonetheless, and despite the absence of a clear framework, the proliferation of trust entities in the past twenty years clearly suggests that the relevant sovereign actors form an interpretative community, in that they share common understandings about the culture and the environment within which trusts are set up and moreover interpret these underlying assumptions in a wholly uniform manner. ${ }^{1}$ Although the contemporary trust vehicle was not intended to serve merely a limited number of usages, its employment in the international sphere serves mainly the following functions: natural disasters, fiscal emergencies, long-term financial stabilisation, poverty alleviation and environmental financing.

The smooth, un-problematic and universally consistent application of the intergovernmental trust paradigm in the midst of a jungle of agreements between the relevant actors and their implementation in domestic legal systems may also be explained by reference to so-called Global Administrative Law (GAL). This generally posits that the biggest part of global regulatory governance may be viewed as administration and that the relevant implementing authorities at both domestic and inter-State level form a global administrative space that is inextricably linked. ${ }^{2}$ Commentators argue that this global administrative space includes also public-private partnerships that are not controlled by a central executive

\footnotetext{
Professor of Public International Law, Brunel Law School.

${ }^{1}$ See S Fish, Is There a Text in the Class? The Authority of Interpretative Communities (Harvard UP, 1980), who coined the theory of interpretative communities.

${ }^{2}$ See B Kingsbury, N Krisch, R Stewart, The Emergence of Global Administrative Law, (2005) 68 Law \& Contemp Probs 15.
} 
authority and are not predicated on formal legal structures. It is posited that a common normative character, of a fundamentally administrative nature, unites otherwise disparate areas of governance and in this manner the transparency of the international regulatory bodies is better guaranteed because of the many intermediate layers from the top executive echelons to the minor domestic implementing agencies. ${ }^{3}$ These observations closely reflect the trust paradigm analysed in this article and are extremely useful in explaining how and why it operates the way it does from the international to the domestic sphere. Nonetheless, my objective in this study is to map the relevant relationships at the international level and not to identify the modalities pertaining to the chain of administration and hence GAL does not play a direct part in this analysis.

At this early point a definition of the fundamental characteristics of intergovernmental trusts may be attempted by reference to the legal instruments employed by States and international organisations. This consists of a contractual relationship between a donor and a trustee for the benefit of a future class of beneficiaries, or an intended purpose, whereby the beneficiaries are distinct from the persons of the trustee or donors and the trustee moreover possesses sufficient independence from the donors to carry out its mandate, although the latter's authority over the trust's decision-making processes may be severely limited. Furthermore, the legal person of the trust is distinct from that of the donors, as well as from the other assets of the trustee, albeit the assets of the trust pass to the ownership of the trustee throughout the duration of the trust relationship. Finally, beneficiaries do not possess equitable rights against the trustee or the trust property, save through a subsequent grant agreement and the donors are not liable against third parties or the beneficiaries, except where an unlawful act may be directly attributed to them. The issue of donor and trustee liability, and its lack thereof, is central in the rationale of intergovernmental trusts and will be explored and challenged more fully below. In any event, this is perhaps a much longer definition than what this author would have wished, but it encompasses all the essential elements of the necessary characteristics of intergovernmental trusts.

One may argue that given the extensive civil law and common law jurisprudence on trusts we should be able, at the very least, to transplant some of their basic elements into their international law counterparts, or alternatively use domestic notions as interpretative tools. This is not a new idea and Judge Fitzmaurice even attempted a similar analogy with common law trusts in his Separate Opinion in the South West Africa cases, in order to explain certain aspects of the trusteeship system. ${ }^{4}$ However, as the reader will come to realise in the course of this article, not only are the two legal traditions themselves at odds on the nature of trusts, but the intergovernmental model itself is also quite distinct. This is not to say that general principles of trust law are of no use; rather, although they cannot be employed to explain the legal nature of the intergovernmental trust per se, they are certainly useful for elaborating the duties of the trustee to the donors, among others, ${ }^{5}$ although this is a matter well beyond the scope of the present study. Ascertaining the legal nature of intergovernmental trusts and their precise place in general international law is much more than a theoretical exercise. Rather, it helps us to distinguish those abusive or disguised trusts that would otherwise be subject to the

\footnotetext{
${ }^{3}$ B Kingsbury, The Concept of "Law" in Global Administrative Law, (2009) 20 EJIL 23, pp 25-27.

${ }^{4}$ South West Africa cases (Ethiopia v RSA, Liberia v RSA), (1950) ICJ Rep 146, p 149.

${ }^{5}$ For example, it is wholly unlikely that a trustee will follow not to choose the common law rule set out in Weisbrand v Salmon [1928] 249 NY 458, per Cardozo J, p 464, according to which he is bound to act in the best interests of the beneficiary. This is also true in respect of the duty of loyalty, as expressed in Nat. Trustees $v$ General Finance Co [1905] AC 373, per Lindley LJ, p 375. In general terms, the transplant of domestic legal concepts into the international sphere is problematic and - despite the existence of general principles - should not arbitrarily be used to substitute consent or consensus-based rules. To the best knowledge of this author, the finest and most successful example of such transplant is in the field of international criminal procedure, which is predicated almost in its entirety on domestic criminal laws.
} 
law of agency or the domestic laws of pertinent States, particularly where they would otherwise be governed by securities and general commercial law. Moreover, it would alleviate concerns that intergovernmental trusts can invest their assets in international markets or transact with private entities without being subject to securities and investment laws, laws regulating anti-competitive practices, or that they can impose interventionist terms on recipient States without even incurring any liabilities. At present, their perceived privileges and immunities are interpreted under this light, particularly because no affected entity has as yet challenged these assumptions; this is even true in respect of a trust vehicle that is in all likelihood abusive of the trust paradigm. . ${ }^{6}$ Although I will not be addressing all of these questions in the present article, I am convinced that an elaboration of the legal nature of these trusts and their place in general international law is fundamental to any further enquiry. ${ }^{7}$

From a methodological point of view, although the fundamental principles of intergovernmental trusts underlie all their operations, because these are administered by independent trustees the modalities for enforcing these principles in practice are premised on the institutional law of each and every trustee. Thus, a transversal approach is adopted in this article in respect of the general underlying principles alone. With regard to the application of these principles by the trustees, the discrete practice of each trustee, along with his institutional law, contractual practices, etc, will be necessarily analysed separately. To these matters, a transversal approach would be ill-advised.

\section{The Fundamental Elements of the Intergovernmental Trust Relationship}

Traces of the trust relationship are found in Ancient Greek law, albeit its most concise formulation in antiquity was encompassed under the Roman law concepts of the fiducia and the fideicommissum. In the Roman law of property the fiducia was employed to denote the trust transfer of property, accompanied always with a further agreement, the pactum fiduciae. On the basis of this agreement the trustee promised the settlor that he would use the property for the fulfilment of a purpose and that he would later return it to him. In case the terms of the pactum fiduciae were not adhered by the trustee, the settlor possessed a special claim against him, the actio fiducia directa, which was predicated solely on its contractual basis and was therefore a claim in personam and thus could not be directed against a third person to which the trustee may have transferred the settlor's property. ${ }^{8}$ Whereas the fiducia is more akin to the civil law concept of trust, it is the fideicommissum that is professed by common lawyers as being the forerunner to the common law notion. ${ }^{9}$ The affinity of the fideicommissum with

\footnotetext{
${ }^{6}$ This comment relates to the Prototype Carbon Fund, discussed more extensively below.

${ }^{7}$ By way of illustration, while the trustee is under an obligation to invest the assets of the trust and whereas many of the operations of the trust may in fact resemble those undertaken by private investors, none of these can readily be governed by bilateral and multilateral investment treaties (BITs and MITs), nor by general foreign investment legislation. These instruments cover the workings of private investors. Indirectly, however, the trustee may be implicated in a foreign investment dispute by reason of disbursing a grant to a private investor. This scenario has not been tested in practice. In Tradex Hellas v Albania, Judgment, (1997) ICSID Review FILJ 197, paras 108-09, the respondent argued that the financial sources of Tradex had originated from offshore accounts, foreign banks and the EC and that therefore the undertaking should not be considered an investment. The ICSID arbitral tribunal rejected this contention not in general terms but because the Albanian Foreign Investment Law did not reject the investment nature of undertakings on account of the source of their finances. The analogy is clear in respect of investments carried out on the basis of a trust grant.

${ }^{8}$ See H F Jolowicz, B Nicholas, Historical Introduction to the Study of Roman Law (Cambridge UP, 1972), pp $285 f f$.

${ }^{9}$ See D Johnston, The Roman Law of Trusts (Oxford UP, 1988), pp 1-7.
} 
the common law concept of trusts is further explained by reference to the missio in rem remedy, which entitled the settlor to claim possession and demesne of the trust property against a third person to whom the trust property was transferred. ${ }^{10}$ Unlike the proprietal remedy (in rem) available to beneficiaries in the common law on account of their equitable interest, as developed by the courts of chancery, the missio in rem is not of this nature; its exercise was dependent on a prior personal suit against the trustee. ${ }^{11}$ Civil law jurisdictions adopted the Roman fiducia model (the basic form of which is the treuhand) which was wholly based on contract with the aim of securing a claim belonging to the trustee, or to secure the rights of the trustee in the administration of the settlor's trust property. ${ }^{12}$ This development was largely predicated on judicial interpretations that culminated in cementing the rights of the trustee over the property and similarly limiting the ability of the settlor to make claims over the trust property by invoking unjust enrichment. ${ }^{13}$ The general position in the common law is that the trust is a creature of equity and that the mandate of the trustee is not at all predicated on contract. Moreover, far from being a third party in the relationship between the settlor and the trustee, the beneficiary enjoys rights in rem over the trust property against all persons and rights in personam against the trustee in his administration of the property.

The aforementioned trust notions were certainly influential in the formulation of the trusteeship system under chapters XII and XIII of the UN Charter, as well as its predecessor under Article 22 of the League of Nations Covenant, the so-called Mandates. ${ }^{14}$ Judge McNair even enunciated what he believed where the general principles common to the domestic laws of nations in respect of trust funds and applied these to explain the trusteeship relationship in the UN Charter and the mandates systems. These general principles were held by Judge Fitzmaurice to consist of the following:

a) that the control of the trustee over the property is limited in one way or another; he is not in the position of the normal complete owner, who can do what he likes with his own, because he is precluded from administering the property for his own personal benefit;

b) that the trustee is under some kind of legal obligation, based on confidence and conscience, to carry out the trust or mission confided to him for the benefit of another person or for some public purpose;

c) that any attempt by one of these persons to absorb the property entrusted to him into his own patrimony would be illegal and would be prevented by the law. ${ }^{15}$

The trust and mandate systems were clearly designed to fulfil a trust function whereby the international community (through the UN, where applicable) represented the settlor/donor, the local population the beneficiary of the administration, whereas the governing entity was deemed to represent the temporary administrator, that is the trustee. The relationship

\footnotetext{
${ }^{10} \mathrm{Id}$, pp 136, 231ff. Such a claim would be successful only where the third party received the trust property in his possession by reason of unjust enrichment.

${ }^{11} \mathrm{Id}, \mathrm{p} 230$.

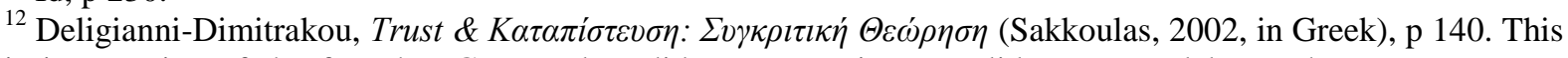
is irrespective of the fact that German law did not recognise as valid contractual bases these two reasons, justifying them instead on the principle of freedom of contract. ${ }^{13} \mathrm{Id}$.

${ }^{14}$ See generally R Wilde, International Territorial Administration: How Trusteeship and the Civilizing Mission Never Went Away (Oxford UP, 2008),

${ }^{15}$ South West Africa cases, Separate Opinion of Judge McNair, (1950) ICJ Rep 146, p 149. It is instructive that in the Certain Phosphate Lands in Nauru case (Nauru v Australia), the Memorial of the Republic of Nauru of April 1990 contained in its Annex a commissioned comparative study on the law of trusts and trust-like institutions by Professor A M Honore. The purpose of the study, among others, was to demonstrate the existence of general principles of domestic laws. Available at: < http://www.icj-cij.org/docket/files/80/6655.pdf >
} 
between the settlor and the trustee was borne and sustained by agreement, in which the mandate lacked perpetuity and the trustee was merely an administrator that possessed no right of ownership over the territory concerned. ${ }^{16}$ As enriching as these principles may be in our discussion of contemporary intergovernmental trusts, they fail to fully encapsulate many of the fundamental characteristics of this international sui generis relationship. For one thing, the trustee was incumbent with concrete obligations against the beneficiaries and the international community as a whole, in accordance with Article 76 of the UN Charter. ${ }^{17}$ Secondly, the beneficiaries could formally petition the settlor and moreover possessed enforceable rights under the laws of the territory and the laws of the trustee pertinent to that territory. Thirdly, the trusteeship and mandate system was restricted to a single type of relationship that concerned the administration of territory. Fourthly, there existed no understanding among the relevant actors that the trustee and the settlor could by mutual agreement limit potential liability arising from the process of administration.

At its very core, the intergovernmental trust consists of a tripartite relationship in which the relevant actors possess asymmetric rights and duties. At the apex sits the appointed trustee who contracts directly with the donors and from which originate the mandate of the trustee and his powers over the allocated resources. The purpose of this contractual arrangement is to ultimately disburse the trust's assets to a class of beneficiaries, which are designated in general terms by the agreement between the donors and the trustee. Whereas the donors are not, and in fact do not wish to be, contractually linked to the beneficiaries, the trustee by necessity is, albeit only following the adoption of a mutual disbursement agreement. In this manner, the trust vehicle serves to divest the donors from all liability towards third parties; or at least, this is the idea and the shared assumption between donors and trustees in all the surveyed trust instruments. Were the donors to contribute financial resources to the same recipients without the medium of the trust, they would naturally incur contractual liabilities, which they would understandably rather avoid. ${ }^{18}$ This is not, however, the sole reason for the existence of intergovernmental trust funds. An additional benefit for the donors stemming from the trust vehicle is the assurance that an experienced trustee will undertake the whole range of managerial, investment and implementation functions related to the trust under consideration. This mechanism is certainly cost-effective for donors, particularly where the trustees, as is the case with the World Bank and the UN, have firsthand experience and physical presence in the country where the funds are to be disbursed and thus the donor need not duplicate existing modalities, engage staff or enter into other commitments. Moreover, whereas a unilateral donation may be perceived as neo-imperialistic or as an invasion of the target State's sovereignty, the medium of an impartial international organisation or of a development bank would avoid bringing about such accusations. Thus, the trust is viewed as a political enabler of international aid, quite apart from its humanitarian dimension.

The trustee, itself an international legal person, is liable to the donors for the performance of his pertinent duties, which are increasingly becoming clearer through the consistent practice of States in this expanding field. This consistent practice relates not to the legal nature of pledges and their disbursement, but to the contractual undertakings between

\footnotetext{
${ }^{16}$ The so-called concept of "sacred trust" ( Art 22(1) League of Nations Charter), which co-existed with that of non-annexation of mandated territories, was designed to limit exploitation by the mandatory, but by all accounts it lacked any practical legal effect. See N Matz, Civilization and the Mandate System under the League of Nations as Origin of Trusteeship, (2005) 9 Max Planck YBUNL 47, pp 70-71.

${ }^{17}$ Certain Phosphate Lands in Nauru case, Preliminary Objections Judgment of 26 June 1992, (1992) ICJ Rep 240, para 41.

${ }^{18}$ Were the donors to make a direct donation to the beneficiary, the mere act of acceptance by the latter would serve to contractualise the arrangement. This is even more the case given that in practice the donors offer funds on the basis of specified qualifications which the beneficiary must thereafter agree to satisfy.
} 
donors and trustees which is clearly aimed at creating binding relations. The trustee's liabilities and powers over the trust's assets and operations are dependent on the trust's power-sharing arrangements between itself and the donors and from any limitations ${ }^{19}$ arising from their mutual contractual relations. The final entity in the tripartite trust relationship, that is the beneficiary, possesses no rights equivalent to remedies in rem (otherwise known as proprietary rights, or rights of equitable interest or of equitable ownership) or in personam against the trustee. This is a clear and express presumption in all trust agreements. A possible avenue for circumventing this absence of remedies may be sought by invoking the fiduciary duties owed by the trustee to the donor. In this case, beneficiaries can attack the trustee's disbursement policies and enforcement through the person of the donor by arguing that since the proper discharge of the function of disbursement belongs within the range of fiduciary duties owed by the trustee to the donors, the failure of the trustee in this regard entails his contractual failure to comply with his fiduciary duties. This alternative assumes, rather wishfully, that the donor will agree to turn against the trustee.

Exceptionally, beneficiaries can turn against the trustee following the adoption of a grant/disbursement agreement with the trustee, claiming thereafter contractual remedies. In my opinion, beneficiaries can also turn against the donors where the latter have played a part in the management of the trust and have caused a wrongful act as a result. This presumption will be explained more fully in a later section. Although it is clear that the fundamental premise of the trust model is to deliver financial assistance by limiting the liabilities of both the donors and the trustee, some indirect avenues are available to prospective beneficiaries. This is true in respect of international compensation trust funds, ${ }^{20}$ particularly those endowed with a judicial or quasi-judicial dimension, as well as with regard to other specialised trusts whereby the beneficiaries are named by a clearly distinguishable class and on the basis of which they constitute numerus clausus. ${ }^{21}$ Equally, the concept of beneficiary may be legitimately expanded to encompass persons, or groups, within a country that are in receipt of funds from an intergovernmental trust. In this manner, said persons or groups can petition the trustee through his institutional organs, where applicable, such as the IBRD's Inspection Panel. ${ }^{22}$ In any event, these beneficiary remedies are limited in both nature and scope. This dimension significantly differentiates intergovernmental trusts from their civil and common

\footnotetext{
${ }^{19}$ See Administration Agreement between the UK and IBRD/IDA Concerning the Multi-Donor Trust Fund for the EITI (TF 053509) (19 Aug 2004) Annex I (Standard Provisions), Art 1, which reads as follows:

"The Bank will be responsible for performing those duties specifically set forth in this Arrangement and will not be subject to any other duties or responsibilities to the Donors, including, without limitation, any duties or obligations that might otherwise apply to a fiduciary or trustee under general principles of trust or fiduciary law. Nothing in this Arrangement will be considered a waiver of any privileges or immunities of the [World Bank] under their Articles of Agreement or any applicable law, all of which are expressly reserved".

${ }^{20}$ In Ilois Trust Fund $v$ Permal, 91 ILR 333, the Board of the Ilois Trust Fund that was set up by the 7 July 1982 UK-Mauritius Agreement contended that it had no duty to compensate an Iloi native, but was instead vested with a discretion to decide on possible beneficiaries. The Agreement made available $£ 4$ million for the settlement of all claims of Ilois people with respect to their removal from the Chagos Archipelago through the establishment of a trust fund, which was subsequently implemented through the adoption of the 1982 Ilois Trust Fund Act. The Mauritius Court of Appeal confirmed the dictum of the trial Court that the scope of the trust fund was to benefit the Ilois individually and collectively. Cause of action for the beneficiaries rested not only on the Agreement itself but also on all previous and subsequent events which aimed to honour said Agreement.

${ }^{21}$ A typical example is the European Agricultural Guarantee Fund (EAGF), EC Regulation 1290/2005 (21 June 2005), O.J. L 209/1 (11 Aug 2005), Arts 3(1)(c) and 11, set up by the EC Commission with the purpose of making "direct payments to farmers under the common agricultural policy". The beneficiaries possess remedies, however, not against the EC Commission, but against the national authorities because these are burdened with a supervisory and enforcement role in respect of implementing the Community budget. See Case 347/85 United Kingdom v Commission [1988] ECR 1749 and Case C-48/91 Netherlands v Commission, [1993] ECR I-5611.

${ }^{22}$ See IBRD Res 93-10 (22 Sep 1993) Establishing the Inspection Panel and particularly para 12, discussing the locus standi of affected groups.
} 
law counterparts in respect of which the existence of equitable beneficiary rights constitutes the cornerstone of the trust relationship. ${ }^{23}$

The precise legal nature of the intergovernmental trust relationship has never been explained or defined in any instrument. While it is true that the intention of the donors and the trustee is to limit their respective liabilities vis-à-vis third parties and beneficiaries, why should one accept this contention absent a framework convention on intergovernmental trusts and sometimes in defiance of general international law? The obvious response seems to be that the basic tenets of donor agreements and trust operational practices are so consistent and uniform that ultimately give rise to a customary sui generis paradigm. I am in agreement with this contention because the aforementioned principles are common to all of the more than 3,000 trust agreements currently in force worldwide. Nonetheless, this does not explain why the purported trust relationship does not amount to an agency or a proxy. An agency may be set up by formal agreement between two international legal persons (whether States or intergovernmental organisations $)^{24}$ by the implicit operation of tacit acquiescence, or through the endorsement otherwise of particular action. ${ }^{25}$ The most poignant outcome of the international law of agency is that the principal is deemed liable for the acts of the agent, as if he had committed these himself. The concept of agency per se does not feature in the text of the 2001 ILC Articles on State Responsibility. Instead, Article 8 of the Articles was intended to resolve the issue of attribution in determining State responsibility, but Sarooshi reluctantly concedes that one may conflate agency and attribution in the same provision with the consequence that "control appears sufficient to establish an agency relationship". ${ }^{26}$ Trust funds under international law are sui generis legal vehicles that although share some of the characteristics of agencies, are in fact very different creatures altogether. Firstly, the donors do not confer any existing State powers to the trustee and through him to the trust entity; the mandate relates to functions and not powers. The trust contract establishes a new set of rights and obligations and it is not intended to alter existing legal relationships. Even so, the formation of an agency would still have been possible, save for the fact that all existing trust agreements clearly stipulate that the agent bears no liability for the acts or omissions of the donors. This exclusion of liability is precisely intended to dissolve any ambiguity as to whether in fact an agency exists and some agreements have exceptionally gone as far as expressly rejecting the existence of any agency relationship from the very outset. ${ }^{27}$ Thirdly,

\footnotetext{
${ }^{23}$ In the common law equitable beneficiary rights are considered rights in rem. See P Birks, In Rem or In Personam? Webb v Webb [1994] 8 Tolley's Trust International 99. This is irrespective of the fact that if ownership of the trust property is transferred to a bona fide third party by the trustee (who does not, as already mentioned, possess ownership over the trust's assets) that third party assumes full and irrevocable title. See Blair v Commissioner of Internal Revenue [1937] 300 U.S. 5. The judgment of the ECJ in Webb v Webb, Case C-294/92, [1994] ECR I-1717, [1994] QB 696, which ruled that an equitable interest is a right in personam must be seen as an aberration, adopted with the aim of retaining a consistent pattern of ECJ jurisprudence with respect to the 1968 Brussels Convention on Jurisdiction and the Enforcement of Judgments in Civil and Commercial Matters (as amended), (1990) 29 ILM 1413 and subsequently the Brussels I Regulation on Jurisdiction and the Enforcement of Judgments in Civil and Commercial Matters, Council Regulation 44/2001 of 22 December 2000, OJ L 12/1 (2001).

${ }^{24}$ France $v$ USA (Case concerning Rights of Nationals of the United States of American in Morocco), Judgment (1952) ICJ Rep 176, pp 185-188.

${ }^{25}$ See Iran v USA (United States Diplomatic and Consular Staff in Tehran), Judgment, (1980) ICJ Rep 3, p 29, where the Court found that although there was no evidence that the new Iranian regime had formally orchestrated the seizure of the US embassy and its staff, it later approved and perpetuated the seizure, thus rendering the culprits agents of the Iranian State.

${ }^{26}$ D Sarooshi, International Organisations and their Exercise of Sovereign Powers (Oxford UP, 2005), p 38.

${ }^{27}$ Art 7 of the Model Inter-American Development Bank (IDB) Donor Agreement for the Establishment of the Anticorruption Activities Fund, IDB Doc CC-6146 (26 Feb 2007), states that "nothing in this agreement may be construed as creating an agency relationship between the Ministry or other contributing donors and the IDB". See also Art II(2)(2) of the Prototype Carbon Fund Instrument, which states that the aim of the parties is to
} 
whereas in the international law of agency the principal and the agent must be distinct legal entities, there is no such requirement in the international law of trusts, although in practice this would be a rare occurrence. Intergovernmental trust funds have been set up where the body of donors does in fact exercise many of the powers of trustee and where an independent trustee was not ultimately appointed. ${ }^{28}$ Fourthly, unlike the agent who may be liable with his own assets, on top of those of the principal, the existing structure of intergovernmental trust funds suggests that in the majority of cases the trust vehicle is an entity independent from the assets of the trustee and itself bears its own liabilities. This is certainly true in respect of trust funds managed by international financial institutions, such as the World Bank, but it is not the case with funds managed by the body of donors, especially where the trust does not enjoy a distinct international legal personality.

A meticulous study of trust agreements reveals the existence, without exception, of the following legally binding duties bestowed on trustees; the duty to keep separate accounts, so long as this is specifically requested by the donors and is in the best interests of the trust; the duty of care; the duty to invest and re-invest the trust's assets in cases of revolving trusts; the duty to avoid conflicts of interest and self-dealing, and; the duty to report to the donors and provide them with regular financial audits. The trustee himself is entitled to a fee for his services, as well as administrative cost recovery, the amounts for which are generally agreed in advance between the parties. Let us now examine some of these fundamental characteristics of intergovernmental trust entities in more detail.

\section{The Contractual Basis of Trusts}

As has already been briefly explained, the position in the common law is that trusts are set up by means of appointment or statute, but certainly not contractually. The situation is different in respect to the Romano-Germanic trust model, whose constitution rests on agreement between the relevant parties. It is clear from the aforementioned discussion that the transposition of either model, whether of the civil or common law-type, in the international legal sphere is only of minor legal value because in both systems the beneficiaries are entitled to some enforceable rights, unlike intergovernmental trusts, as already explained. The contractual basis of intergovernmental trust funds is fully confirmed by extensive practice that knows of no exceptions. This does not mean that the UN Security Council is powerless to set up a trust and endow it with particular powers, given that it has already done so and generally enjoys this power as a result of its implied powers; rather, the Council has never obliged UN member States parties to contribute assets to such funds, nor forcefully appointed a member as trustee. Nonetheless, the contractual nature of trusts should be not be determined strictly in terms of the binding authority of the instrument employed, but in accordance with the degree of consent afforded by the participating actors. It should be noted from the outset that the contractual nature of intergovernmental trusts encompasses two distinct agreements. As will be explained in a later section, the agreement setting up the trust, if any, is separate from a subsequent bilateral agreement between trustee and donor by which the latter consents to his participation thereto and through which he formally pledges the amount of his contribution.

create a trust and not a "general partnership, limited partnership, joint stock association, corporation, bailment or other".

${ }^{28}$ As is the case with the 2004 Global Crop Diversity Trust Constitution, wherein the contributing States assume the role of trustee. 
Given the limited number of available trustees to these vehicles, each has adopted its own institutional rules and policies in order to agree with potential donors on the modality of trust relationships. The varieties of trust instruments and the legal forms they assume does not necessarily imply inconsistent practice or significant deviations from the trust paradigm as defined above. On the contrary, these variations are the direct result of the trustees' efforts to harmonise trust instruments with their own institutional law, which is substantially older than, and predates, the practice of intergovernmental trusts. The fundamental principles permeating all trusts are the same everywhere. It is instructive that in the context of the League of Nations' mandate system the participants recognised more than one legal form of territorial administration. Thus, C-class mandates, under Article 22, such as that endorsed by the 1919 UK-New Zealand-Australia Agreement on Nauru, clearly provided for administration "under the laws of the mandatory as integral portions of its territory". This range of possible mandates did not render the basic mandate relationship inconsistent and this is true even when, as in the case of the 1919 Nauru Agreement, the parties contracted to exclude other League members from equal opportunities in the fields of commerce and trade, in violation of Article $22 .{ }^{29}$ Equally, were a particular trust entity to deviate from a principle whose nature was merely permissive, such as through the granting of enforceable beneficiary rights, its practice cannot be deemed abusive of the general paradigm. Nonetheless, despite the aforementioned consistency in respect of the fundamental principles underlying intergovernmental trusts, it is only through an examination of the institutional law of each one of these that the reader can appreciate the finer intricacies of the emerging trust paradigm. In much the same way, although no doubt should exist as to the emergence of a corpus of fundamental principles underlying the institutional law of international organisations, it is only through the particular law of each one of these organisations that the general principles make any sense.

In accordance with its operational policies, the World Bank, when acting as a trustee, enters into framework agreements with the donors. ${ }^{30}$ Under said policies donors are required to enter into an additional Trust Fund Administration Agreement on the basis of which the Bank recovers its costs to manage and administer the trust fund. ${ }^{31}$ The elaborate mechanism by which the above agreements are drafted, signed and implemented, as well as the absence of any "lighter" - non-binding - alternative, suggests that the intention of the World Bank is to conclude binding treaties with contributing States, rather than contracts subject to private law. In fact, the Bank, where possible, enters into standard binding agreements with all donors to a particular trust fund in order to harmonise results and reduce cost. ${ }^{32}$ The Bank's Standard Provisions applicable to each trust fund are expressly stated in each Letter of Agreement as forming an integral part thereof. ${ }^{33}$ In respect of the Global Environmental Facility (GEF), to which the IBRD acts as trustee, much like other treaties, the GEF

\footnotetext{
${ }^{29}$ See Certain Phosphate Lands in Nauru case, Nauru Memorial, supra note 15, pp 24ff and 186ff, where it is stated that the USA was discontent with the practice of C-class mandates because they had the character of general monopolies. The UN Trusteeship Council was also subsequently critical of the Nauru administrators on account of the fact that no care was taken as to the fate of the indigenous population at the point of exhaustion of the phosphate.

${ }^{30}$ IBRD Operational Policy (OP) 14,40 on Trust Funds (January 1997), Art 1 and IBRD Bank Procedure (BP) 14.40 on Trust Funds (January 1997), Art 1, updated by OP/BP 12.00 on Disbursement (April 2007).

${ }^{31}$ OP 14,40, id, Arts 7-8.

${ }^{32}$ Agreement between the UK and IBRD/IDA for the ASEM-EU Asian Financial Crisis Response Fund (TF 020147) of 29 June 1998; Agreement between Denmark and IBRD/IDA for the ASEM-EU Asian Financial Crisis Response Fund (10 Nov 1998) (both on file with author).

${ }^{33}$ Id.
} 
Instrument ${ }^{34}$ requires that participating entities deposit an instrument of participation to the GEF Secretariat. For States parties this is tantamount to an instrument of ratification, since it is required that this instrument "be signed on behalf of the Government by a duly authorised representative thereof". 35 The deposit of this instrument is required only once. The second contractual relationship between the GEF trustee and participating States is that premised on the instrument of commitment, ${ }^{36}$ through which participating entities make their pledges to the GEF. ${ }^{37}$ Both contracts create rights and duties for the signatories, such as the obligation to pay the pledge and the right to sit in the GEF's Council and Assembly, among others.

Further proof that these agreements constitute treaties and not memoranda of understanding that generally lack an intention to commit is demonstrated by the language employed in these instruments. For example, in the Agreement between the EC Commission and the World Bank for the ASEM Trust Fund of 23 December 1998, it is stated in relevant part: "We are pleased to confirm the intention of the Commission to make available to the World Bank the sum of ...". Equally, "the contribution shall be used for the purposes ..." and "the Commission shall deposit...", whereas "the Bank shall make available to the competent bodies of the EC, upon request, all relevant information...". 38

In cases where the UN Secretariat acts as a trustee to a trust fund, although not always consistently, donors may be requested to engage in a binding agreement with the UN, but there is no such institutional requirement. Article 6 of the Terms of Reference of the UN Special Missions Trust Fund requires that:

The making of a pledge and its acceptance are to be recorded in an exchange of letters, or if deemed appropriate, in a formal agreement. 39

This provision, which is a verbatim reflection of the relevant paragraph in the UN SecretaryGeneral's Bulletin on the Establishment and Management of Trust Funds, ${ }^{40}$ refers to the form of the pledge only and not the contractual modality for the participation of the donor in the trust fund. The latter relationship is distinguished in the Bulletin and in the case of general trust funds it does even require a written agreement. Such an agreement is required only when it "is deemed necessary", ${ }^{41}$ albeit no further guidance exists in elaboration of this requirement. On the contrary, technical cooperation trust funds always require the conclusion of a written agreement. ${ }^{42}$ It is clear, therefore, that general trust funds set up by the Secretariat and the General Assembly do not require a formal arrangement between the donors and the United Nations, let alone a treaty. This practice is no doubt part of the UN's budgetary legacy of failing to treat pledges as binding promises that give rise to a legal obligation. It is only at the moment of receipt or deposit that the donor is bound to honour the pledge. Prior to this it

\footnotetext{
${ }^{34}$ The Restructured GEF Instrument, adopted by IBRD Decision 94-2 (24 May 1994), is reproduced in (1994) 33 ILM 1273, as subsequently amended in March 2008. See J Werksman, Consolidating Governance of the Global Commons: Insights from the GEF, (1995) 6 Yearbook Int'l Environmental Law 27.

${ }^{35}$ Id, GEF Instrument, Annex A.

${ }^{36} \mathrm{Id}$, Annex C2.

${ }^{37}$ A new Instrument of Commitment needs to be deposited every time parties pledge money or where they are requested to replenish the resources of the GEF. See para 2(a), IBRD Exec. Directors' Res 98-2 (14 July 1998) on Second Replenishment of GEF Resources.

${ }^{38}$ TF 020147, Project No ALA/ASI/98/0419, preamble (on file with author).

${ }^{39}$ The same is not, however, stipulated in the Trust Fund for Preventive Action (TFPA), established by the UN Secretariat's Political Affairs department.

${ }^{40}$ ST/SGB/188 (1 March 1982), para 29.

${ }^{41} \mathrm{Id}$, para 31.

${ }^{42}$ Id, para 32. In fact, in respect of technical cooperation trust funds there exists a model agreement as set out in the Secretary-General's Administrative Instruction for Technical Cooperation Trust Funds, UN Doc ST/AI/285.
} 
is merely considered an expression of intent to provide a voluntary contribution of assets, lacking compulsion, unless otherwise agreed. ${ }^{43}$

As a consequence, it is evident that the adoption of treaties between the trustee and State/intergovernmental organisation donors is not a general requirement in the international law of trusts, although it is good practice where the trustee is able to enforce them through the adoption of binding instruments. Where the trustee is a UN specialised agency or a UN Programme, such as the UN Environmental Program (UNEP), which alone manages a sizeable amount of international trust funds, none of the surveyed Terms of Reference require UNEP to conclude donations in the form of treaties. ${ }^{44}$ As a result, UNEP's agreements with donors can take many legal forms, ranging from treaties to MoU, ${ }^{45}$ even where donations are granted in respect of similar projects and sums. ${ }^{46}$ The same is true with regard to donor agreements accepted by the UNDP. The UNDP's Financial Regulations and Rules require the conclusion of an agreement but fail to specify its legal nature. ${ }^{47}$ It is thus possible for donor agreements consummated with the UNDP to possess a non-binding character under the UN rationale analysed above. In practice, however, the UNDP has set up a model trust administration agreement which it now employs in its relationships with all its donors. It should not be thought that the adoption of a MoU instead of a treaty is more beneficial to the contributing State. On the contrary, it would seem that a binding treaty is a secure basis for confirming the rights and duties of the parties, given that it is in the interests of the trustee and the fund itself to bind the contributors to the amount of their pledge. The likely benefits of an $\mathrm{MoU}$ are perhaps its speedy conclusion and adoption, particularly where the donation is below a particular threshold, its confidentiality, as well as the avoidance of a perpetual obligation. $^{48}$

Yet another reason for the avoidance of otherwise binding instruments, particularly in the UN system, concerns the desire to attract private donors. However, given that contracts must be "substantially the same" so as to ensure equality of treatment of the contracting entities, the governing law will be different in the trustee's agreements with the private donors; this is most likely to be the law of the seat of the trustee, but where the contract is to be performed in a third territory the applicable law may well be the law of that country. This

\footnotetext{
${ }^{43}$ See J E Archibald, Pledges of Voluntary Contributions to the United Nations by Member States: Establishing and Enforcing Legal Obligations, (2004) 36 Geo Wash Int'l LR 317, pp 317-18, 329. Archibald rightly comments that with regard to unpaid voluntary contributions the UN does not invoke Art 19 of the UN Charter, pp 325-26.

${ }^{44}$ COP Decision VCI/9 (28 April 1989) [Vienna Convention on the Protection of the Ozone Layer], available at: <http://ozone.unep.org/Publications/VC_Handbook/Section_2_Decisions/Article_6/Decs-

financial_matters/Decision_VCI-9.shtml\#Annex\%20III>.

${ }^{45}$ Even though the general intention of the parties in concluding a MoU is the avoidance of entering into a binding instrument, we are in agreement with the position that the normative character of a MoU is judged both by its content and the intention of the parties. The two may sometimes be conflicting, but certainly one should not disregard the wish of the parties not to be bound by the terms of an agreement. A Aust, Modern Treaty Law and Practice (Cambridge UP, 2003), pp 26-34, 41-46.

${ }^{46} \mathrm{MoU}$ between Swedish Ministry of Sustainable Development and UNEP (Feb 2005); see also UN-HABITAT MoU with Canada for Contributing to the Water and Sanitation Trust Fund.

${ }^{47}$ UNDP Financial Regulations and Rules (April 2000), Reg 5.07(a). Rule 108.1 states that trust funds shall be established either on the basis of a written agreement, or by the issuance of its terms of reference, in anticipation of receipt of contributions by prospective contributors.

${ }^{48}$ See A Aust, The Theory and Practice of Informal International Instruments, (1986) 35 ICLQ 787. Lipson has added to this list the desire to avoid formal and visible pledges, the desire to avoid ratification, the ability to renegotiate or modify as circumstances change, as well as the need to reach agreements quickly. C Lipson, Why are Some International Agreements Informal? (1991) 45 Intl Org 495, p 500. Moreover, Bilder has argued that States may choose the option of non-binding accords out of a desire to manage more efficiently the risks of international agreement. See R B Bilder, Managing the Risks of International Agreement (Madison, 1981), pp $24 \mathrm{ff}$.
} 
equally entails the existence of an asymmetric relationship in which the trustee's liabilities are limited by reason of his privileges, whereas the private party will bear the full range of personal liabilities without restriction. ${ }^{49}$ In reality, this is not such a pressing issue because international organisations incur full liability where they violate the terms of their contracts with private actors. The adoption of non-binding private instruments should not be excluded where the institutional rules of the trustee either allow, or omit reference to, such informal arrangements. The World Bank's policies generally exclude the possibility of such agreements, whereas the UN specialised agencies that administer trust funds have taken a varied approach to the legal modalities of private contributions. ${ }^{50}$ The legal nature of the agreement will also depend on the type of contribution made. It is common for private contributors, particularly those in a specific industry, to donate in-kind, rather than cash. ${ }^{51}$

In some cases the entity of the trust and the parties' pledges thereto may be constituted through a single agreement. Given that private entities may partake in the operations of such a trust fund, it becomes imperative to ascertain whether this single trust agreement is a treaty, a combination of treaty and domestic contract provisions, or whether it is in fact a domestic contract applicable equally among all parties. It should be noted from the outset that the prevalent view is that international organisations may theoretically be set up even by domestic contract, so long as their overall function is of a purely governmental/public nature. ${ }^{52}$ By analogy, the same is true in respect of intergovernmental trust funds. A detailed analysis of this phenomenon is beyond the scope of this article. However, it suffices to say that there does not seem to exist any legal impediment to the creation of a two-tier agreement, parts of which operate as treaty provisions among member States, while others assume a contractual nature between States, the trustee and private actors.

Many donors, for whatever reasons, do not wish to partake in the organisational, fundraising, or other structure of the trust and are simply content to deposit, through a bank transfer, money into the account of the trust. Prima facie, it would seem that the deposit or transfer of a donation into a bank account held by the trustee is a unilateral act that is devoid of legal compulsion because it does not establish any further legal obligations and corresponding rights for the trust fund or the trustee, particularly where it is not preceded by a contractual agreement by which the State has undertaken to make the contribution. This assumption is untrue for a number of reasons. For one thing, the act of deposit serves to implement the pledge, irrespective of whether this was originally considered as giving rise to legitimate expectations or not. Secondly, upon deposit into the account of the trust, that entity's terms of reference come into operation and may render, where applicable, its assets

\footnotetext{
${ }^{49}$ It is usual for trustees to be mandated by the donors to enter into arrangements with the private entity in order to provide it with tax deductibility allowances in respect of its donation. See Art 27(a)(i)(2) of the Global Fund for AIDS Framework Document, GF Doc. GFATM/B1/Doc. 4 (18 Jan 2002). Otherwise, the relevant financial or operational regulations clearly stipulate that no special advantages or benefits should accrue to private donors, such as Art 6 of the World Bank's OP 14.40. Equally, s 2.13 et seq of the World Bank Trust Fund Hand-Book, IBRD Doc 17304 (April 1997) warns the Bank, when acting as trustee, to avoid providing any benefits to private investors that would give rise to a conflict of interest or a distortion of its procurement rules.

50 Art 18 of the UN Secretary-General's Guidelines on Cooperation between the UN and the Business Community (17 July 2000) envisages five types of partnership arrangements. Of interest in this connection is para (a) dealing with direct contributions, whereby it is advised that this be accommodated through a trust fund or special account agreement with the partner subject to the applicable Rules and Regulations of the UN.

${ }^{51}$ In 2003 the pharmaceutical corporation Novartis agreed to provide TB medicine for the treatment of 500,000 sufferers over a period of five years. This undertaking was consummated through a MoU and not a binding contract. The medicines were delivered to the Global Drug Facility (GDF) of the Stop TB Partnership for use in programs supported by the Global Fund against AIDS, Tuberculosis and Malaria. IFPMA, Partnerships to Build Healthier Societies in the Developing World (Sep 2006), p 37, available at: <http://www.lmi.no/IFPMA_Building_Partnerships_Eng_18Jul06_0K6Fy.pdf.file>.

${ }^{52}$ ILC Report on Responsibility of International Organisations, UN Doc A/CN.4/532 (26 March 2003, p 15.
} 
immune from suits and further oblige the trustee to invest and disburse the trust's assets, among others. ${ }^{53}$ If the deposit, therefore, was merely a unilateral act that was devoid of any legal effects, the contributing State could at any time claim the reimbursement of the money contributed on the basis that by its action of deposit it had not created any legitimate expectations vis-à-vis the trust fund or the trustee. Thirdly, the deposit of the contribution by the donor State must necessarily be met with a corresponding acceptance by the private bank where the trust's account is held and also by the trustee. In some cases this acceptance may be tacit, but even so it will no doubt be recorded somewhere, whether in the private bank's records of deposit or the trustee's official audits. Normally, as is consistent with audit practices, the trustee is required under his internal rules and regulations to approve the contribution and make a clear record of it. ${ }^{54}$ That this constitutes a clear correspondence of the wills of the respective parties is confirmed by the fact that the trustee may refuse to accept the donation where the contribution has been earmarked by the donor to the dissatisfaction of the trustee,${ }^{55}$ or where it is deemed inconsistent with the terms of the trust fund.

Moreover, the trust agreement is hierarchically superior, at least in the UN system, over the financial rules and regulations of the UN's specialised agencies, in the sense that it may provide authority to the trustee (where the trustee is not the United Nations or a subdivision thereof) to audit the financial management of the specialised agency where the latter is acting as an implementing or other entity. ${ }^{56}$

\section{Applicable Law}

References to applicable law are made throughout this article depending on the subject matter under discussion. It is useful, nonetheless, to consolidate this issue under a single section for purposes of clarity. Where a trust fund possesses sufficient international legal personality to interact with States under its own name it will do so via treaties or MoU, both of which are governed by international law. The relationship between a trust that has been granted limited international legal personality by a Headquarters Agreement and the granting State will be determined on the basis of that Agreement, which usually stipulates for the applicability of a substantial corpus of domestic law, in addition to some international law. ${ }^{57}$ Equally, in their transactions with private parties, intergovernmental trusts, irrespective of their legal organisation, will typically stipulate a particular domestic law as the applicable law to their

\footnotetext{
${ }^{53}$ It is common practice for public international financial institutions, such as the World Bank, to require State donors, on the basis of their respective treaty, to send a copy of their deposit instruction to their Accounting Trust Funds department, as well as instruct the private bank where the donation has been deposited to notify the Bank. See Administration Agreement between the UK and IBRD/IDA Concerning the Multi-Donor Trust Fund for the Extractive Industries Transparency Initiative (TF 053509) (19 Aug 2004, on file with author).

${ }^{54}$ Rule 103.5 of the UN's Financial Regulations and Rules, UN Doc ST/SGB/2003/7 (9 May 2003), requires the approval of the Organisation. Equally, under Reg 3.12, moneys accepted for purposes specified by the donor shall be treated as trust funds. These provisions are cited in order to clarify that unilateral deposits are not treated by the receiving organisations as mere unilateral acts that lack legal effect.

${ }^{55}$ E.g. Reg 27 of the ICC Regulations of the Trust Fund for Victims, Doc ICC-ASP/4/Res. 3 (3 Dec 2005) states that voluntary contributions from States shall not be earmarked. Interestingly, Reg 26 stipulates that the Board shall establish mechanisms for the verification of the sources of funds received by the Trust Fund. This is further evidence of the binding character of the deposit of funds, even though prima facie a deposit resembles a unilateral transaction that does not produce legal effects.

${ }^{56}$ UN Legal Counsel Opinion of 14 February 1995, (1995) UNJYB 413, pp 414-15.

57 Agreement between the Swiss Federal Council and the Global Fund for AIDS, TB and Malaria, in View of Determining the Legal Status of the Global Fund in Switzerland, GEF Doc GF/B7/7, Annex 9. See infra notes 172-75.
} 
contracts. This does not, however, exclude the application altogether of international law whether implicitly or by reason of the contract itself, if the parties so wish.

In the majority of cases the trust entity will have conferred its contractual powers to the trustee, which will typically be an international development bank or some other international organisation, such as the UN. As a result, the contractual practices of these organisations become relevant in any attempts to discern the applicable law. By way of illustration, the IBRD and IDA subject their loan and credit arrangements with State entities ${ }^{58}$ to public international law, ${ }^{59}$ subject to very minor and specific exceptions in respect of necessarily local matters such as the creation of sureties. On the other hand, the European Investment Bank (EIB) subjects its arrangements with States to a given national law. ${ }^{60}$

Where the entire gamut of the contractual transactions of a trust fund are performed by its trustee, the applicable law and terms of said contracts are most commonly predicated on the trustee's institutional requirements and internal by-laws. The United Nations, for example, in its contractual relations with private entities (e.g. contractors) appends thereto as an integral part its General Conditions of Contract, with particular variations in respect of contracts for construction, ${ }^{61}$ the provision of goods, ${ }^{62}$ consultancies and others. This instrument is rather favourable for the UN. The applicable law in respect of individual contracts is a matter for negotiation between the parties and as a result it is not stipulated in the General Conditions, which do, however, oblige the parties to settle their disputes through an arbitral mechanism, should other amicable means fail. ${ }^{63}$ The practice of the IBRD is somewhat different and section 1.01 of the 2006 General Conditions for Loans stresses that "if any provision of any legal agreement is inconsistent with a provision of these General Conditions, the provisions of the legal agreement shall govern". This affirms that in the IBRD's legal relationships with third parties there are situations whereby its institutional law is by no means imperative, whereas in respect to others the Bank's institutional law is a sine qua non requirement of the transaction. The latter is true, at least, with regard to the Bank's consent in setting up and administering trust funds.

The UN Legal Counsel has made it clear that the Organisation can incur liabilities of a private nature, particularly where they arise from transactions arising from contracts, purchase orders, leases and other agreements. ${ }^{64}$ Equally, therefore, the choice of forum and lex arbitri is a matter to be settled by agreement between the parties. ${ }^{65}$ The governing law of

\footnotetext{
${ }^{58}$ The IBRD typically enters into loan and guarantee agreements with borrowing States, upon which these States assume full responsibility for carrying out the project in respect of which the funds were borrowed. Where the direct borrower is a private entity the Bank will enter into a Guarantee Agreement with the government of the relevant member State.

${ }^{59}$ General Conditions Applicable to Loan and Guarantee Agreements (1985), s 10.01 (in accordance with which the Agreement expressly prevails over any domestic law to the contrary); General Conditions for Loans (as amended through 16 Oct 2006), s 8.01, and; General Conditions Applicable to Development Credit Arrangements (1985, as amended 2 Dec 1997), s 10.01.These General Conditions, much like those of the UN, constitute integral components of subsequent agreements with recipient States and are implicitly binding on the parties. See IDA-Chad Development Credit Agreement (Management of the Petroleum Economy Project), Credit No 3316 CD (20 March 2000).

${ }^{60}$ HJ Hahn, Agreements for the Provision of Credit and Financial Guarantees by States under Public International Law, in CCA Voskuil, Z Parac, JA Wade (eds.), Credit and Guarantee Financing Transfer of Technology, (Martinus Nijhof, 1987), p 6.

${ }^{61}$ UN Special Conditions for Construction Works, available at: 〈http://www.ci.undp.org/ptd/pdf/speccon.pdf〉.

${ }^{62}$ See UN General Conditions of Contracts for the Provision of Goods (as revised in Jan 2008), available at: <http://www.un.org/Depts/ptd/pdf/general_condition_goods.pdf >.

${ }^{63}$ Id, s 18(2).

${ }^{64}$ Legal Opinion of 23 February 2001, (2001) UNJYB 381, at pp 384-85.

${ }^{65}$ It may also be determined by the courts in some cases. For example, the recent practice of English courts is to subject the governing law of the arbitration clause, in the absence of an express stipulation by the parties, to the
} 
private contracts entered into between international organisations and private entities is usually designated by reference to the law of the seat of the international organisation, particularly where the private party's operations lie therein. Conversely, where the performance of the contract is to be undertaken in a territory other than the seat of the organisation, especially where these are of a small scale not involving significant resources, said contracts will be governed by the national law of the country where the service is provided. Loan agreements with private entities entered into by the IBRD and the IMF are governed either by the law of the place of the loan or by the law on whose territory the private contracting banks are incorporated, or by the law of the State of New York. ${ }^{66}$ In every case, the relevance of international law should not be underestimated, even in contracts between the trustee and private entities, as well as in those cases where the parties have not even designated international law as their choice of law. ${ }^{67}$

\section{The Donor Agreement does not Necessarily Establish the Trust Entity}

The trust agreement between the appointee (or donor) and the trustee may, but does not necessarily or ipso facto establish the entity of the trust fund. For certain, it acts as an instrument of appointment, followed by a further obligation by the trustee to set up the trust fund by means of an internal institutional act, usually by opening a bank account and thereafter arranging the modalities for deposits, financial maintenance and disbursement. This is the standard practice of the World Bank Group, the leading trustee of humanitarian projects financed by States. ${ }^{68}$ One should therefore distinguish between the requirement of agreement between the donor and the trustee in order for the donor to contribute assets and/or participate in the institutional workings of the trust fund (what we may term as the process of trusteeship), from the very fact of setting up a trust fund in the first place (the creation of the trust entity). One may call this the "separability dimension" of intergovernmental trust funds, which works much in the same way as the doctrine of separability in the law of arbitration. An intergovernmental trust fund may be set up without any existing donors, in the expectation of prospective donors. This qualified fund may be achieved by means of an intrainstitutional act of an intergovernmental organisation. On the contrary, no State may be forced to contribute to a trust fund, as this would lack the element of consent and would no

\footnotetext{
law of the seat, rather than the proper law of the main contract. See $C v D$ [2007] EWCA Civ 1282, [2008] 1 Lloyd's Rep 239 (CA). This position is not, however, shared in all other jurisdictions.

${ }^{66}$ Art 11(a), IMF-Monetary Agency of Saudi Arabia Loan Agreement, IMF Decision 6843 (81/75), 6 May 1981, cited in P Sands, P Klein, D W Bowett, Bowett's Law of International Institutions (Sweet and Maxwell, 2001), p 462.

${ }^{67}$ This follows the practice of ICSID, where despite the express stipulation of a particular domestic law by the parties to their contract, and Art 42 of the ICSID Convention that allows parties to determine their applicable law, the tribunals have been particularly vocal about the application of international law, even above the clear dictates of the agreed domestic law. See Compañia del Desarrollo de Santa Elena S.A. v Costa Rica, Award, (2000) 15 ICSID Review - FILJ 169, p 191. similarly, in Wena Hotels Ltd v Arab Republic of Egypt, Decision on Annulment (5 Feb 2002), (2002) 41 ILM 933, an ICSID ad hoc committee rejected an annulment claim on the basis that the arbitral tribunal had manifestly exceeded its authority by ignoring the parties' choice of law (i.e. Egyptian law), applying instead the substantive provisions of the relevant BIT and other international law. This is always going to be the case where a chosen domestic law is in conflict with a rule of general international law and where moreover international law is an integral part of the proceedings.

${ }^{68}$ The World Bank practically sets up a trust fund not only by opening a bank account, but formally through the adoption of an executive resolution that has the effect of bringing the fledgling fund within its institutional remit, both for internal Bank purposes as well as vis-à-vis third parties. This was the case, for example, with the establishment of the GEF fund through IBRD Exec. Directors' Res 91-5 (14 March 1991).
} 
doubt contravene the most fundamental premise of the law of international trust funds. It is for this reason that the UN Secretary-General's Bulletin on the Establishment and Management of Trust Funds distinguishes between trust funds (which are based wholly on voluntary contributions) from special accounts (which are funded in whole or in part from assessed contributions). ${ }^{69}$ The Bulletin expressly highlights the fact that although the UN Secretariat and the General Assembly may set up trust funds as a matter of institutional law, the participation of donors therein requires some form of agreement. ${ }^{70}$

Certain trusts, particularly those that do not envisage the appointment of an external trustee and which are premised solely on treaties between States, incorporate within the body of the treaty both the agreement between the participants as well as the normative establishment of the trust. In this manner, the trust is deemed as existing from the moment of ratification of the treaty. This two-in-one type of agreement is rare and generally concerns those trusts composed of a limited and closed number of States. The Tuvalu Trust Fund is of this nature, having been set up by a multilateral treaty between the UK, Australia, New Zealand and Tuvalu, with the aim of contributing to the long-term financial viability of Tuvalu by providing an additional source of revenue in respect of the government's recurrent expenses that would ultimately lead to financial autonomy. ${ }^{71}$ This model is quite prevalent in respect of all those trust entities derived from multilateral treaties that are also designated by their drafters as constituting international organisations. The Tuvalu Trust is itself an international organisation, as is also the Global Crop Diversity Trust and the Common Fund for Commodities.

Exceptionally, those multilateral treaties that envisage the creation of trusts for the purpose of victim compensation generally require the promulgation of an additional normative act, usually a decree approved by parliament, which dresses the trust with domestic legal personality. This is the case with the Foundation Remembrance, Responsibility and the Future Fund (Remembrance Fund), set up on the basis of a multilateral agreement $^{72}$ and in respect of which the Fund is an entity under German public law. ${ }^{73}$ The same considerations as those outlined above in relation to the Remembrance Fund are also true with respect to the Austrian General Settlement Fund (GSF) that was established on the basis of the 2001 Washington Agreement between Austria and the USA with the purpose of compensating victims of the Austrian Nazi-era regime. ${ }^{74}$

The practice of States in the formation of intergovernmental trusts clearly stipulates that there exist no limitations as to the legal organisation of the entity of the trust. Thus, we have already made reference to trusts incorporated as full international organisations, which is certainly not the rule. Trusts are otherwise organised as mere bank accounts without a trace

\footnotetext{
${ }^{69}$ Supra note 40 , para 5 .

${ }^{70} \mathrm{Id}$, paras 31-33.

${ }^{71} 1987$ Agreement Concerning an International Trust Fund for Tuvalu, 1536 U.N.T.S. 48.

${ }^{72}$ The parties first adopted a Joint Statement on occasion of the Plenary Meeting concluding International Talks on the Preparation of the Foundation "Remembrance, Responsibility and the Future", adopted on 17 July 2000 , available at: <http://germany.usembassy.gov/germany/img/assets/8497/jointstatement.pdf>. On the same day, a formal Executive Agreement (of 17 July 2000) Concerning the Foundation "Remembrance, Responsibility and the Future was adopted, (2000) 39 ILM 1298, which recorded, among others, the parties' wish to establish the trust.

${ }^{73}$ Law on the Creation of a Foundation "Remembrance, Responsibility and Future", 2 Aug 2000 (Federal Law Gazette I 1263), as amended by the Law of 21 Dec 2006 (Federal Law Gazette I 3343).

74 BGBI. III 121/2001, Joint Statement and Annexes, available at: <http://www.en.nationalfonds.org/docs/BGB1_III_Nr_121_2001.pdf>. The Agreement was followed, as prescribed therein, by the promulgation of the General Settlement Fund Law (GSF-Law), BGBI. I 12/2001. See H Lessing, R Rebernik, N Spitzy, The Austrian General Settlement Fund: An Overview, in Permanent Court of Arbitration (eds.), Redressing Injustices through Mass Claims Processes: Innovative Responses to Unique Challenges (Oxford UP, 2006), pp 95ff.
} 
of independent personality other than that of the trustee; as limited international organisations on the basis of a Headquarters agreement that only has bilateral effect and by which trusts are generally registered as special domestic law foundations; as subsidiary organs of international organisations; as informal conferences without any international legal personality. ${ }^{75}$ In respect of those trusts that do not possess any domestic or international legal personality, all transactions on their behalf are undertaken through the person of the trustee but under their name. This is done in order to distinguish the trust's assets from those of the trustee. In every other respect, the very fact of the trust relationship whereby the trust's assets are held in ownership by the trustee serves to protect them in the same way as the trustee's own assets. Nonetheless, in practice, it is not unusual for trusts lacking legal personality to contract directly with other persons, legal or physical, as a matter of necessity. However, because this situation may potentially create problems for those trusts that are devoid of legal personality, their creators are increasingly formally endowing them with the requisite amount of personality that will enable them to carry out their day-to-day affairs. ${ }^{76}$

\section{Justifications for Creating the Entity of the Trust on the basis of the Institutional Law of the UN and the World Bank}

We have already determined that whereas the agreement between the donors and the trustee sets in motion the pooling of the required financial resources, the actual creation of the trust vehicle generally rests on an additional act of the trustee. It is not self-evident that international organisations can readily assume the role of trustee, nor that they have the power to give birth to trust funds on the basis of their institutional and implied powers. Even if the organisation under consideration was found to be competent to act as trustee and set up trust entities, it does not follow that all the organs within the organisation possess that capacity also. The following sections attempt to shed some light on this issue.

\section{The IMF Special Facilities as Trust Paradigms}

Trust funds established by the International Monetary Fund (IMF) share many of the characteristics of other intergovernmental trust funds, but are unique in the sense that the IMF is both creator (in the sense that there exists no external mandate by a pool of prospective donors), trustee and partial contributor to the financial resources of its trusts, ${ }^{77}$ although this

\footnotetext{
75 Typical examples of such emergency funds that lack a formalised legal personality are the International Reconstruction Fund Facility for Iraq (IRFFI), the Multi Donor Trust Fund for South Sudan (MDTF-SS), as well as the GEF. Informal associations of States that yield significant powers are not a new phenomenon. The CSCE/OSCE does not possess international legal personality, yet it has undertaken most of the EC and NATO's post-conflict operations in Europe and the Caucasus. See M Sapiro, Changing the CSCE into the OSCE: Legal Aspects of a Political Transformation, (1995) 89 AJIL 631. In fact, the CSCE Declaration of 6 December 1994 and the Decision on the Strengthening of the CSCE, para 29, (1995) 34 ILM 767, made it clear that the change in name did not alter the legal status of this entity.

${ }^{76}$ Para 11 of the 2008 (unedited version of the) Decision of the COP to the 1997 Kyoto Protocol, confers upon the Adaptation Fund Board "such legal personality as [is] necessary for the discharge of its functions with regard to direct access by eligible parties and implementing and executing agencies... in particular legal capacity to enter into contractual agreements and to receive projects, activity and programme proposals directly and to process them... as appropriate".

77 This is possible in accordance with Art V(2)(b) of the IMF's 1945 Articles of Agreement, 2 U.N.T.S 39. However, this provision does not explicitly stipulate the ability to establish trust funds, but this possibility is inferred from the competence to "perform financial and technical services ... that are consistent with the
} 
practice is also common within the UN system. It will become evident in this section that the IMF's special trust funds entail diverse legal relationships between the trustee and the borrowers and between the trustee and the trust's creditors. In any event, it is obvious why the IMF would choose to perform the functions of trustee to trust funds it has itself established; it has the experience, know-how and technical mechanisms (e.g. access to financial resources, assets and links with member State contributors that are willing to provide assets in respect of particular funding mechanisms) to carry out such tasks. Another practical consideration is that the trust funds created by the IMF are created for the benefit of, and tied to, programmes tackling debt-relief, poverty alleviation and balance of payments in the developing world, which are themselves created and managed by the IMF and which fall within its ambit of programmatic objectives.

The principal legal basis for establishing an IMF or IBRD trust fund is their respective Articles of Agreement, albeit there are no provisions therein that pertain to the establishment of trusts. The Articles, however, stipulate that the World Bank entities must use their resources and facilities for the benefit of their members ${ }^{78}$ and the employment of trusts is certainly a mechanism designed to give effect to this mandate. On the basis of this undertaking the IBRD adopted its operational policies and procedures in respect of establishing and managing trusts. ${ }^{79}$ This legal basis has allowed the IMF to adopt so-called Instruments and set up trust funds as principal accounts and sub-accounts thereof. Unlike other trust funds examined in this article, IMF trust funds established as accounts and subaccounts do not possess and do not aspire to possess any form of international legal personality outside the legal person of the IMF. Indeed, there is no practical reason why this should occur, since the functions, assets and personnel of the account/trust fund are protected by the privileges and immunities of the IMF under its Articles of Agreement. ${ }^{80}$ Another practical implication is that the external contributors "contract" with the IMF and not the account. Moreover, it is evident that the lack of a delegated complex trustee structure makes the whole enterprise far more cost-effective. A typical example is the Instrument for a Framework Administered Account for Technical Assistance Activities [Framework Account]. ${ }^{81}$ That the Framework Account is a trust is evident from section 1 of the Instrument, which states as its purpose;

... the administration of resources to be contributed by: (i) governments or other official agencies of countries and (ii) inter-governmental organisations ... in order to finance technical activities of the [IMF].

Given that the contributors to the trust fund possess international legal personality, the Instrument of which omits all references to private entities, these must necessarily enter into specific donor agreements with the IMF. In accordance with section 2 of the Instrument the resources provided by the donors shall be either: a) grants, or; b) proceeds of grants or loans

purposes of the IMF". As will be explained in a following section the UN Secretary-General, among others, has had the dual role of creator and trustee of trust funds, such as the ICJ and ITLOS Trust Funds.

${ }^{78}$ IBRD Articles of Agreement, Art III(1)(a).

${ }^{79}$ World Bank Procedure (BP) 14.40, Trust Funds (Jan 1997). The IBRD normally establishes trust funds on the basis of its operational procedure, followed thereafter by a resolution of its Executive Directors. It is the agreement with the donors that sets up a trust relationship and not the resolution. Exceptionally, the Board may set up a trust fund without agreement with donors with a view to mobilising the international community in respect of a persistent problematic situation. A notable example is the Trust Fund for Gaza, for which the IBRD's Board first adopted Res 483 (11 Nov 1993), with which it approved a transfer, by way of a grant, from the surplus to the Trust Fund. The Fund itself was established by IBRD Res 93-11 (19 Oct 1993) and IDA Res 93-7 (19 Oct 1993). See I Shihata, The World Bank in a Changing World (Martinus Nijhoff, 1995), pp 385-86.

${ }^{80}$ IMF Articles of Agreement, supra note 77, Art IX.

${ }^{81}$ IMF Decision 10942-(95/33) (3 April 1995), the most recent amendment to which was effected by IMF Decision 12641-(01/126) (6 Dec 2001). 
that have been received by the donor from entities other than the IMF, i.e. from private or public banks, or similar financial institutions. The transfer of the latter type to the IMF may, in fact, require multiple transactions because the proceeds of such a grant may be in the possession or account of a private financial institution, or somehow be owed to the donor State/intergovernmental organisation by a third party. Equally, since the relevant instruments permit donors to contribute loans they have taken out for the purposes of the particular trust fund, it may very well be decided that the private (or public, or central) bank providing the loan must transfer the money/ financial assets to the IMF through a single or multiple transactions. The elaboration of such transactions are beyond the scope of this article, but it suffices to say that where the grant or its proceeds are transferred to the account of the IMF by a private bank, even where it is acting on behalf of the State/international organisation, such payments through bank transfers are subject to private banking law unless otherwise stipulated. ${ }^{82}$ The same is obviously not true with the agreement/commitment to contribute to the trust fund, which is assumed as a legal obligation by the State/international organisation vis-à-vis the IMF and which is governed by international law and is, moreover, subject to the law of treaties. However, such agreements for additional funding between donors and the IMF are not necessary and donor States can equally proceed on the basis of unilateral declarations or by making an oral pledge to the trust fund and thereafter entering into an agreement with the recipient/borrower with the aim of cancelling a pre-existing debt of the borrower.

The instruments that establish the trusts have received little analysis as to their legal nature. With respect to the relationship between the IMF as trustee and the donors, is it prudent and feasible to view it as operating under the guise of primary or "secondary treaties"? As a primary treaty the instrument would be the only source of obligation for the parties, while as a "secondary treaty", although not subject to signature or ratification, the instrument would nonetheless constitute a valid legal basis of obligation because explicit reference would be made to it in the bilateral donor agreements, in which case the bilateral donor agreement would constitute the basis of mutual obligation. The reality of course is that since the instruments are adopted as decisions by the executive board of the IMF they do not possess the normative traits of treaties, but serve as IMF institutional law. Nonetheless, the bilateral donor agreements, where indeed they are found to exist, if at all, must necessarily conform to the provisions of the Instruments and as such the instruments necessarily operate as "secondary treaties", since the trust fund instrument is intended by the parties to govern their legal relationships. This hypothesis does not mean that the instruments are treaties by nature, but where a bilateral agreement exists between the trustee and the donor these either become an integral part of the bilateral agreements or alternatively the donor agreements must be interpreted in full conformity with the trust instruments. Either way, the same result is achieved.

Subsequent IMF trust funds expressly noted that the relevant instruments are indeed intended to establish a trust fund and that the IMF was to act as trustee. Equally, as already pointed out, the IMF utilised trust funds in order to finance ongoing efforts to tackle poverty, underdevelopment and Third World debt by setting up a variety of trust vehicles and by combining its various initiatives therein. Examples include the Heavily Indebted Poor

\footnotetext{
${ }^{82}$ See J Dalhuisen, Dalhuisen on International Commercial, Financial and Trade Law (Hart, 2004), pp 427455. Rights in rem, involving ownership of immovable property by intergovernmental organisations, are subject to the lex situs rule, whereas other contractual arrangements between such organisations and private parties are subject to national or transnational law, in accordance with the terms of the parties' agreement. Claims in tort involving private entities would be usually subject to the lex loci delicti commissi, rather than the lex forum. See C F Amerasinghe, Principles of the Institutional Law of International Organisations (Cambridge UP, 2005), pp 387-89.
} 
Countries (HIPC) Initiative, the Poverty Reduction and Growth Facility (PRGF) and the Exogenous Shocks Facility, all of which are inter-related. The IMF commenced a practice as early as 1976 of providing concessional financing to low-income countries through the establishment of a trust fund which loaned the profits generated from the sale of part of the IMF's holdings. The relative success of this trust vehicle was later followed by the establishment of a Structural Adjustment Facility (SAF) whose aim was to recycle resources loaned under the trust fund itself. A year later an Enhanced SAF came into being with the additional aim of putting in place stronger adjustment and reform measures. ${ }^{83}$ In 1991 its name was changed even further and it became known as the Enhanced SAF to the Poverty Reduction Growth Facility and was later replaced by the Poverty Reduction Growth Facility. ${ }^{84}$ The setting up of accounts (otherwise described as facilities) to achieve the purposes of trust funds were thus employed through the following instruments, among others: the Instrument to establish a Trust for Special PRGF Operations for the Heavily Indebted Poor Countries and Interim PRGF Subsidy Operations (Special PRGF Trust); ${ }^{85}$ the Instrument to establish the Poverty Reduction and Growth Facility and Exogenous Shocks Facility Trust (PRGF-ESF Trust) ${ }^{86}$ the Instrument to establish the Multilateral Debt Relief Initiative-I (MDRI-I Trust). ${ }^{87}$ Unlike the vast majority of intergovernmental trust funds that generally finance identified activities in the form of non-reimbursable donations, the IMF's trust funds disburse assets to beneficiaries in the form of highly preferential loans. PRGF loans are disbursed under three-year arrangements, subject to observance of performance criteria and the completion of program reviews. Loans carry an annual interest rate of 0.5 percent, with a 5-1/2 year grace period and a 10-year maturity.

As far as the relationship between the IMF as trustee and the borrowers is concerned, this is not wholly clear from the terms of the relevant instruments. Certainly the IMF does not expressly subject these to the regime of stand-by-arrangements under Article XXX(b) of its Articles of Agreement, nor is it possible to assimilate them to extended arrangements because the financial resources loaned to the borrower are not derived from the IMF's General Resources Account, as is otherwise required in respect of extended arrangements. In order to decipher the precise legal nature of this relationship one has to assess the practice of the Fund. Thus, eligibility for a loan under the PRGF requires the submission of a so-called Poverty Reduction Strategy Paper (PRSP) by the borrower, in consultation with civil society, in which the borrower must sufficiently elaborate and explain his financial situation, the steps taken to improve it and in what ways the loan under the terms of the PRGF would be utilised, as well as elaborate on the expected outcome. This is a typical example of assigning full local ownership to the requesting State through the adoption of PRSP that are country-owned and therefore country-specific in orientation. These PRSP are in fact no different from the Letters of Intent required for stand-by-arrangements which the IMF has consistently described as being non-contractual in nature. In practice, PRGF and HIPC borrowers submit such reports to the IMF under both designations as either PRSP or letters of intent, in anticipation of a

\footnotetext{
${ }^{83}$ IMF Executive Board Decision No 8757-(87/176) SAF/ESAF and Decision No 8759-(87/176) ESAF of 18 Dec 1987.

${ }^{84}$ The decision was endorsed by the IMF Interim Committee by Decision No EBS/99/193 of 14 Oct 1999. See P Isard, Globalisation and the International Financial System (Cambridge UP, 2005), p 90.

${ }^{85}$ IMF Decision 11436-(97/10) (4 Feb 1997), the most recent amendment to which was effected by Decisions 13588-(05/99) MDRI and 13590-(05/99) ESF (23 Nov 2005).

${ }^{86}$ IMF Decision 87-59-(87-176) ESAF (18 Dec 1987), the most recent amendment to which was effected by Decision 13689-(06/24) ESF (10 March 2006).

${ }^{87}$ IMF Decision 13588-(05/99) MDRI-I Trust Fund (23 Nov 2005).
} 
PRGF or HIPC loan. ${ }^{88}$ More specifically, in order to be considered for HIPC Initiative assistance, a country must: (1) be IDA-only and PRGF-eligible; (2) face an unsustainable debt burden that is beyond traditionally available debt-relief mechanisms; (3) establish a track record of reform and sound policies through IMF and IDA-supported programs; and (4) have developed a PRSP on the basis of broad public consultation. Once a country has met or made sufficient progress in meeting these criteria the Executive Boards of the IMF and IDA formally decide on its eligibility for debt relief and the international community subsequently commits itself to reducing debt to the agreed sustainability threshold. Where this is achieved, a country reaches its so-called "decision point" and may thereafter immediately begin receiving interim relief on its debt. In order to receive the full and irrevocable reduction in debt available under the HIPC Initiative, however, the country must: (i) establish a further track record of good performance under IMF- and IDA-supported programs; (ii) implement satisfactorily key reforms agreed at the decision point, and (iii) adopt and implement the PRSP for at least one year. Once a country has met these criteria it can thereafter reach its completion point, at which time lenders are expected to provide the full debt relief committed at the decision point. ${ }^{89}$ There is a clear intention, therefore, on the part of the IMF to avoid contractualisation of this relationship under the same terms as its stand-by-arrangements on the basis of its Board's executive decision. This is certainly the personal understanding of this author. This non-contractual nature is further reinforced by the practice of some borrowers to append a memorandum of understanding (MoU) to their PRSP, which is intended to serve the same function as reservations and interpretative declarations to multilateral treaties, although as we have already stressed that the IMF's decisions to grant loans are not considered treaties, but are treated as internal decisions that lack a contractual character. It is the very fact that the borrower chooses to employ the services of an MoU to explain his implementation of the imposed conditionalities that the non-contractual character of these arrangements vis-à-vis the borrower can be confirmed.

Unlike the compulsory contributions to the IMF's General Account by its members on the basis of their obligations under the Fund's Articles of Agreement, contributions to the Fund's special trusts is not restricted to Fund members, States or intergovernmental organisations. ${ }^{90}$ The relevant provisions are almost identical and by way of example, section II of the Special PRGF Trust Instrument notes that:

The trustee may accept contributions of resources for the Account on such terms and conditions as may be agreed between the trustee and the respective contributors, subject to the provisions of this Instrument. For this purpose, the Managing Director of the trustee is authorised to accept grants and enter into loan, deposit or other types of investment agreements with the contributors to the Trust.

The texts of the instruments pose no visible limitations to contributors. In practice, given that neither the General Arrangements to Borrow (GAB) nor the New Arrangements to Borrow (NAB), through which the IMF receives financial contributions that are additional to its members' Special Drawing Rights (SDR), involve private entities it is wholly implausible to assume that an exception is possible in respect of the IMF's trust funds. This assumed limitation would not exclude central banks and public banks. On the other hand, there is no visible reason under the terms of the trusts' instruments to assume the exclusion of private contributions and there does not seem to be any legal impediment to this effect either. The

\footnotetext{
${ }^{88}$ See Lao People's Democratic Republic: Second Poverty Reduction Strategy Paper, IMF Country Report No 08/341 (Oct 2008); Gambia, Letter of Intent in respect of Third Review under PRGF Arrangements (30 July 2008).

${ }^{89}$ See <http://www.imf.org/external/np/exr/facts/hipc.htm>.

${ }^{90}$ MDRI-I Fund Instrument, s II; Special PRGF Trust Instrument, s II; PRGF-ESF Trust Instrument, s IV(2).
} 
only possible limitation that may be read in the texts is the commitment by the IMF to use contributions in respect of the stated purposes of the relevant trust fund, which is also a requirement in relevant IBRD trust funds. ${ }^{91}$ Other than that, private persons face no institutional impediment in contributing resources to the IMF's special accounts.

Practice confirms this conclusion. In fact, the PRGF and the MDRI, as do all the IMF's special trust vehicles, rely on the additional contributions of member States, ${ }^{92}$ as well as on those of private entities, particularly in the area of debt relief. ${ }^{93}$ Under the HIPC and MDRI, contributions are not only received by the positive act of depositing financial assets, but more importantly by agreeing to extinguish pre-existing debts owed to them by HIPC and MDRI-eligible States. Debt relief under these IMF initiatives has been supplied in one of two ways: a) by the Paris Club, which is an informal group of nineteen sovereign creditors among the globe's industrialised States that meets in Paris with the aim of offering debt relief and/or debt restructuring. Since the adoption of the PRGF the Paris Club has offered better debt restructuring to HIPC-eligible countries than non-HIPC countries. At the time of writing, and since the mid-1950s, the Paris Club has entered into more than four hundred debt relief agreements with debtor States. ${ }^{94}$ Participating creditor countries and the debtor country usually sign an Agreed Minute at the end of a negotiation session. This is not a legally binding document but merely a recommendation by the heads of delegations of participating creditor countries to their governments to sign a bilateral agreement implementing the debt treatment. When there are only a few creditors concerned the Paris Club agreement is exchanged through mail between the Chair of the Paris Club and the government of the debtor country, and is called terms of reference. In some cases the multilateral debt agreement takes the form of an MoU. Either way, one has to examine the particular language of the respective agreements in order to ascertain their binding or non-binding nature. As regards non Paris Club creditors, they typically enter into bilateral agreements with debtor States, either under the HIPC or independently of it. Numerous bilateral agreements have been concluded in this manner whether as treaties or MoU. ${ }^{95}$ It is, therefore, evident that the IMF's special facilities/trust funds are not based in all their dimensions on the Fund's institutional law, as is the case with its stand-by-arrangements. Rather, the Fund's trustee relationship with its debtors is institutional, whereas its relationship with creditors - as well as that between creditors and the debtors in some cases - is contractual.

\footnotetext{
${ }^{91}$ For example, the 21 Sep 1999 Agreement between China, the IBRD and the IDA for the ASEM-EU Asian Financial Crisis Response Trust Fund stated in relevant part that "the contribution shall be used for the purposes described in the Standard Provisions Applicable to Grants to the Trust Fund, attached hereto as Annex I, which forms an integral part of this Letter of Agreement" (on file with author).

${ }^{92}$ See ECB Opinion of 11 August 2005 Concerning a Draft Federal Law on the Payment of a Contribution by Austria to the Trust Fund Administered by the IMF for Low Income Developing Countries Affected by Natural Disasters, ECB Doc CON/2005/29, whereby the ECB confirmed that such contributions are consistent with the obligations of parties with Art 101(2) of the EC Treaty.

93 The IMF defines debt relief as "Agreements by creditors to lessen the debt burden of debtor countries by either rescheduling interest and principal payments falling due over a specified time period, sometimes on a concessional basis, or by partially or fully cancelling debt service payments falling during a specified period of time.

${ }^{94}$ See, e.g., Paris Club Press Release (24 Jan 2008) on a Reduction of the Debt of the Gambia in the Framework of the Highly Indebted Poor Countries Initiative (HIPC), available at: <http://www.clubdeparis.org/sections/services/communiques/gambie/viewLanguage/en>.

${ }^{95}$ See IMF, HIPC Initiative: [Report on the] Status of Non-Paris Club Official Bilateral Credit Participation (10 Oct 2007), pp 7-11. The IMF and the Paris Club have identified several legal impediments to debt relief agreements. Among these one may note: a) impediments arising where central banks are the holders of the debt; b) those cases where some creditors have argued that the mandate of specialized agencies holding guaranteed claims does not allow them to provide debt relief at HIPC Initiative terms; c) sale of HIPC claims to private investors, which increases the likelihood of litigation. Id, IMF HIPC Report, pp 12-13.
} 


\section{United Nations Special Accounts}

The UN Secretary-General's Bulletin on the Establishment and Management of Trust Funds states that the Organisation recognises two types of trust funds: general and technical cooperation trust funds. ${ }^{96}$ General trust funds are set up to support any activity other than technical cooperation. Thus, they may be used to "expand the work program of one or more organisational units of the Secretariat, or for humanitarian and relief purposes to provide direct assistance in respect of emergency situations". They may be of a continuing or longterm nature or simply for a specific duration. ${ }^{97}$ Technical cooperation trust funds, on the other hand, are such that provide economic and social development assistance to developing countries. This may include the provision of experts and associate experts by the donor State, the financing of training initiatives and the provision of project equipment. ${ }^{98}$

The Bulletin differentiates between these two types of trust funds, which are the only entities defined as such, from all other special accounts whose funding is derived from extrabudgetary resources. Thus, only the two types of trust funds (i.e. general and technical cooperation) are subject to the provisions of the Bulletin and not those voluntary funds that are subject to the administrative authority of their respective heads, such as UNICEF, UNDP, UNFPA, the funds of the UN High Commissioner for Refugees and others. ${ }^{99}$ This is also true in respect of voluntary accounts set up to finance peacekeeping and related operations, which are not to be regulated as trust funds under the Bulletin, but solely in accordance with the UN's Financial Regulations and Rules. The rationale for this differentiation lies in the fact that the majority of peacekeeping operations are generally financed from assessed, rather than voluntary, contributions. ${ }^{100}$ As a result, it is logical to subject them to a different legal regime, albeit two conclusions seem reasonable: a) peacekeeping missions that are funded through voluntary contributions may be regarded as trust funds for UN financing purposes, ${ }^{101}$ and; b) special accounts do in fact constitute trust funds in the general legal sense despite their financing from assessed contributions. Their distinction from other UN trust funds is only valid as such in respect of the UN's institutional law.

The various principal organs of the United Nations have set up so-called special accounts in order to either finance projects in respect of which additional funds were required

\footnotetext{
${ }^{96}$ UN Doc ST/SGB/188 (1 March 1982), para 4. Specialised agencies within the UN system are free, however, to recognise further sub-specialisations of trust funds in accordance with their mandates and institutional law. Thus, UNEP, in addition to general and technical cooperation funds, distinguishes between the following categories of trust funds: a) those that provide direct support for implementation of the UNEP program of work; b) those that provide support for UNEP-administered conventions, protocols and regional seas programs, and; c) those belonging to a special category of trust funds supporting activities supported by UNEP. This latter category includes, among others, the Trust Fund serving the 1987 Montreal Protocol on Substances that Deplete the Ozone Layers, (1987) 26 ILM 1550 [Ozone Layer Convention Fund] and all trust funds funded by the GEF for which UNEP is an implementing agency. See Report of UNEP Executive Director on Environment Fund Budgets: Proposed Biennal Programme and Support Budget for 2008-09, UNEP Doc GC/24/9/Add.2 (1 Dec 2006), p 7.

${ }^{97}$ Secretary-General's Bulletin on Trust Funds, supra note 40, para 13.

${ }^{98} \mathrm{Id}$, para 15.

${ }^{99} \mathrm{Id}$, para 5.

${ }^{100} \mathrm{Id}$, para 4(c).

${ }^{101}$ Such as, for example, the UN Peacekeeping Force in Cyprus (UNFICYP), which was partly financed by voluntary contributions. SC Res 186 (4 March 1964), para 6. In fact, a third of the mission's contributions have come through voluntary means from the governments of Cyprus and Greece. See Report of the SecretaryGeneral on the UN Operation in Cyprus, UN Doc S/2007/699 (3 Dec 2007), paras 37-40. The remainder is financed by means of assessed contributions.
} 
apart from the regular UN budget, or where such a special account was imposed by the Security Council. I shall restrict my analysis to trust funds established as special accounts by the General Assembly, the Secretary-General and the Security Council for both of the aforementioned scenaria. It will be demonstrated, as already mentioned, that these special accounts are in fact true trust funds. In the case of the Secretary-General and the General Assembly, although their authority to establish trust funds may stem from Security Council resolutions or as a direct result of their implied powers, it is also grounded in Regulation 4.13 and Rule 104.3 of the UN's Financial Regulations and Rules. ${ }^{102}$ That these entities are consistent with the general definition of intergovernmental trusts provided above is evident from the following: a) they are predicated on a tripartite contractual relationship in which neither the trustee nor the donors derive a personal benefit; b) the financial contributions held by the UN, as trustee, are held separately from other accounts and the UN regular budget; c) the UN's liability in respect of each trust account is limited to the funds contained in that account alone. These trusts are distinguishable from the UN's regular budget because the latter is not predicated on a tripartite relationship, but only on one that involves the UN and its members. Moreover, the regular budget cannot exist absent the legal person of the Organisation, which is not the case with trust funds because they do not require their incorporation into a legal person. Finally, although member States are not generally responsible for the acts undertaken by the Organisation, the latter cannot exclude its liability against third parties by means of unilateral declarations or by means of any implied understanding.

\section{Special Accounts and Trust Funds of the UN General Assembly}

During the Cold War, at which time the General Assembly undertook the role of organising peacekeeping, peace monitoring and peace enforcement operations around the globe, it necessarily also undertook the task of fundraising for the costs associated with these operations. As contributions to such missions could not be sought from the UN's regular budget alone, ${ }^{103}$ extraordinary contributions were solicited by the General Assembly by ordering member States to pay weighed assessments, whereby permanent Security Council members and economically developed States would share the bulk of the expenses, while developing States would pay a far smaller contribution. Resolution 43/231, for example, requested the Secretary-General to establish a special account in order to finance the UN Angola Verification Mission. ${ }^{104}$ States were ordered to pay assessed contributions on the basis of the scale analysed.

It is significant that despite the omission in naming a trustee in the relevant resolution, the text necessarily suggests that this is the Secretary-General through the UN Secretariat. Under the terms of the Angola Verification Mission, for example, the Secretary-General is not only responsible for setting up the special account (operative paragraph 1), but is moreover

\footnotetext{
${ }^{102}$ UN Doc ST/SGB/2003/7 (9 May 2003).

${ }^{103}$ UN peacekeeping operations are generally funded by separate assessments on the basis of a complex formula, as opposed to voluntary contributions alone. See S Ogata, Financing an Effective United Nations (1993), p 6. In the Certain Expenses of the United Nations, Advisory Opinion (Art 17(2) UN Charter), (1962) ICJ Rep 151, pp 169-170, the ICJ made it clear that an authorised obligation of the UN may be paid by using funds from the regular budget or a special account or fund.

${ }^{104}$ GA Res 43/231 (16 Feb 1989); see also GA Res 43/228 (21 Dec 1988), Financing the UN Disengagement Observer Force; GA Res 43/229 (21 Dec 1988), Financing of the UN Interim Force in Lebanon, both of which either established a new special account or supplemented the funds of an existing one.
} 
... requested to take all necessary action to ensure that the [Mission] is administered with the maximum of efficiency and economy bearing in mind the relevant observations contained in the report of the Advisory Committee on Administrative and Budgetary Questions. ${ }^{105}$

Hence, unlike the IMF trust accounts, in respect of which the IMF was both creator and trustee, the General Assembly's special accounts are set up by the Assembly but administered by the Secretary-General in his natural capacity as chief administrator of the Organisation. The trustee's duties and mandate are set out in the resolution itself and by its very nature each special account is distinct from the funds of the UN's general budget or other specialised accounts or trust funds. The resolutions further allow for additional funds to be donated, in which case a fiscal transaction would be required between the Secretary-General and the donating State, since special accounts do not possess independent legal personality, although naturally the trustee can contract with third parties under their name.

These special accounts should be contrasted from other voluntary trust funds established by the General Assembly, particularly in the field of human rights. These are subjected to the Secretary-General's Bulletin on the establishment of trust funds as described above. The legal bases, structure and mandate of all such voluntary trust funds are identical. The three most prominent are the Voluntary Fund for Indigenous Populations, ${ }^{106}$ the Voluntary Fund for Victims of Torture ${ }^{107}$ and the Voluntary Fund on Contemporary Forms of Slavery. ${ }^{108}$ For one thing the legal basis for each is a General Assembly resolution. Unlike the special accounts that concerned budgetary issues and more particularly contributions to the UN's peace-keeping missions, for which the Assembly may adopt binding resolutions, ${ }^{109}$ the human rights trust funds under consideration involve only voluntary contributions and therefore do not fall within the Assembly's authority to pass binding resolutions. Secondly, although the UN Secretary-General is mandated to serve as their administrator, there is also provision for an independent board of trustees to effectively manage and provide fiduciary duties. No such governance or trustee structure exists with regard to the Assembly's special accounts. Therein the boards of trustees, although independent, maintain only a supervisory capacity and do not possess any decision-making authority over matters pertinent to disbursement. Thirdly, on the basis of their mandate, it is unarguable that the Assembly's voluntary trust funds do indeed possess a significant degree of international legal personality, as distinct from their creator, and as such qualify the characterisation of subsidiary organs of the Assembly. ${ }^{110}$ In practice, the Assembly may "appropriate" trust funds originally set up by the Secretary-General in the form of subsidiary organs under its authority, as was the case with the UN Fund for Population Activities (UNFPA). This trust fund was originally established by the Secretariat in 1969 but was subsequently incorporated under the authority

\footnotetext{
${ }^{105}$ GA Res 43/231, operative para 5.

${ }^{106}$ GA Res 40/131 (13 Dec 1985). The mandate of the Fund was expanded by GA Res 56/140 (19 Dec 2001).

107 GA Res 36/151 (16 Dec 1981), which replaced and consolidated the UN Trust Fund for Chile, initially established under GA Res 33/174 (20 Dec 1978).

${ }^{108}$ GA Res 46/122 (17 Dec 1991).

109 Art 17, UN Charter; UN Financial Regulations, Reg 4.5 and Rule 104.2 regarding the Assembly's powers over the Peacekeeping Reserve Fund.

${ }^{110}$ Indeed, the creation of subsidiary organs by the Assembly is permissible under Arts 7(2) and 22 of the UN Charter. Whether the Assembly may turn a trust fund into a subsidiary organ depends on the nature of such an organ and whether it is deemed necessary for the exercise of the particular function by the Assembly. Advisory Opinion on Application for Review of Judgment No 158 of the UN Administrative Tribunal [Fasla Opinion] (1973) ICJ Rep 166. There is no reason why a trust fund whose purpose does not conflict with the Council's peace and security mandate cannot qualify for subsidiary organ status, especially if this is the overwhelming intention of the Assembly's members. See D Sarooshi, The Legal Framework Governing United Nations Subsidiary Organs, (1996) 67 BYIL 413.
} 
of the Assembly in 1972. ${ }^{111}$ In construing this incorporation from an institutional perspective, the Office of the UN Legal Counsel noted that Article 22 of the UN Charter certainly authorises the Assembly to establish subsidiary organs, presumably even in the aforementioned manner involving subsequent adoption by one principal organ to the detriment of another. ${ }^{112}$ Finally, both types of trust funds are capable of receiving private donations although in the case of the voluntary trust funds this is likely to be a major source of income. Equally, both types are administered in accordance with the Financial Regulations and Rules of the UN. ${ }^{113}$

\section{Special Accounts and Trust Funds of the UN Security Council}

This section deals with trust funds established by the Security Council and one should, therefore, distinguish situations in which the Council directly sets up a trust fund from those where it simply welcomes the establishment of a particular trust, even if the entity setting it up has itself been created by the Council, as would be the case with a Security Council subsidiary organ. ${ }^{114}$ These trust funds and special accounts are not subject to the SecretaryGeneral's Bulletin on trust funds, because that instrument only regulates funds and special accounts set up by the General Assembly and the Secretariat.

Following the Gulf War in 1990 the Security Council determined in paragraph 16 of Resolution 687 that Iraq was "liable under international law for any direct loss, damage ... or injury to foreign governments, nationals and corporations, as a result of Iraq's unlawful invasion and occupation of Kuwait". ${ }^{115}$ In accordance with paragraph 18 of the Resolution the Council decided to create a trust fund (Kuwait Compensation Fund) and an administering Compensation Commission that would put the modalities in place to assess relevant compensation claims, which would exist alongside a trust vehicle from which Iraqi assets would be channelled to compensate injured parties. The Compensation Fund was to be replenished by financial assets derived from the sale of petroleum by Iraq (export sales). The Secretary-General, who was entrusted with formulating an appropriate mechanism, proposed that the Fund be set up as a special account subject to the UN's Financial Regulations and Rules. ${ }^{116}$ He further proposed that the Compensation Fund/Special Account be administered by the Compensation Commission, and in particular the Commission's Governing Council as this was envisaged in Resolution 687 in the form of a Security Council subsidiary organ. ${ }^{117}$ The Report put forward three alternatives as to the Fund's practical existence, whereby surprisingly only one alternative was not endowed with some share of international legal personality; this was a simple escrow account. The other two alternatives envisaged: a) the

\footnotetext{
${ }^{111}$ GA Res 3019 (XXVII) 18 Dec 1972.

112 Thus, the UN Legal Counsel concluded that "as a consequence of the adoption of General Assembly resolution 3019, the Fund ceases to be a trust fund of the Secretary-General and becomes a Fund under the authority of the General Assembly with an intergovernmental governing body, having its own financial regulations and rules ... [and as a result] became a subsidiary organ of the Assembly similar to other Funds having intergovernmental supervisory bodies, such as UNICEF, the Capital Development Fund and the United Nations Special Fund”. UNJYB (1979), p 172.

${ }^{113}$ Similar trust funds are established also by other organs of the UN, such as ECOSOC, which set up the Voluntary Fund for Technical Cooperation in the Field of Human Rights Introduction through the adoption by the UN Human Rights Commission of Res 1987/38 (10 March 1987).

${ }^{114}$ E.g., the UN East Timor Trust Fund was set up by UNTAET and was welcomed in SC Res 1272 (25 Oct 1999).

${ }^{115}$ SC Res 687 (8 April 1991).

${ }_{116}^{116}$ UN Doc. S/22559 (2 May 1991), p 2.

${ }^{117} \mathrm{Id}$.
} 
Fund as the sole or co-beneficiary on the bill of lading or other title and any letter of credit issued, following which the Fund would retain its share and remit the remainder to Iraq; b) an escrow account endowed with privileges and immunities and designated beneficiary to the bills of lading, etc, administered by a central bank or appropriate international institution. ${ }^{118}$ Unlike the General Assembly's special accounts, the Secretary-General seems to have been conscious that exigencies may have required the Fund Account to not only contract and hold assets in its name, but also to operate as an equal partner across various jurisdictions, as well as with intergovernmental organisations apart from the legal personality of its trustee. We are not suggesting that the Secretary-General envisaged a quasi-intergovernmental organisation, although it is beyond doubt that he certainly suggested endowing it with some degree of legal personality that is absent from other UN special accounts.

Eventually, the Compensation Fund and the Commission were created by the Council ${ }^{119}$ and although the escrow account-type was preferred no definitive legal personality was attached to these accounts. However, given that the Council adopted subsequent resolutions whereby it set up additional escrow accounts, which were administered by the Secretary-General and were further endowed with particular privileges and immunities, it seems fair to argue that in fact the Kuwait Compensation Fund does possess a degree of international legal personality. ${ }^{120}$ The escrow accounts/funds established by Council resolutions 706 and 712 were new interim trust funds and the two resolutions authorised the import by UN member States of Iraqi petroleum products for a six month period, up to the amount of US $\$ 1,6$ billion, in order to finance all the operations mandated under Resolution 687. Such proceeds were to be deposited in the two escrow accounts and from there transferred to the Compensation Fund, ${ }^{121}$ among others. However, when Iraq failed to satisfy the compensatory terms of all previous resolutions and in order for the Compensation Commission to carry out its work it was decided that an amount be advanced from the UN Working Capital Fund. The situation had not been remedied by 1995 when the Council adopted Resolution 986 by which thirty percent of Iraqi oil sales would be allocated to the Compensation Fund. ${ }^{122}$ The mechanism envisaged in Resolution 986 was the so-called "Oilfor-Food" programme and although it took almost twenty months to bring it into effect the money deposited in the Compensation Fund enabled it to function effectively. ${ }^{123}$ Proceeds from the oil-for-food programme were themselves to be deposited in two separate accounts/funds. ${ }^{124}$ Following the deposition of the Hussein regime in the aftermath of the 2003 Iraq war the Security Council requested the Secretary-General to terminate the oil-forfood programme and amend to five percent the percentage of export sales of all Iraqi petroleum products deposited in the Compensation Fund. ${ }^{125}$

No doubt, the historical analysis of the Compensation Fund depicts a complex web of legal relationships. The Compensation Fund is composed of two distinct entities; the Trust Fund in the form of a special escrow account and the Compensation Commission, consisting

\footnotetext{
${ }^{118} \mathrm{Id}, \mathrm{pp} 5-6$.

${ }^{119}$ SC Res 692 (20 May 1991).

${ }^{120}$ SC Res 706 (15 Aug 1991) and SC Res 712 (19 Sep 1991). In these the Council decided that all related Iraqi petroleum assets were immune from legal proceedings and not subject to any form of attachment or execution. Equally, it decided that the escrow accounts enjoyed the privileges and immunities of the United Nations, as did also the inspectors and experts on mission on behalf of the UN.

${ }^{121}$ SC Res 778 (2 Oct 1992), operative paras 1, 10.

${ }^{122}$ SC Res 986 (14 April 1995).

${ }^{123}$ SC Res 1330 (5 Dec 2000) reduced to twenty-five percent the amount of revenues from the Oil-for-food programme.

${ }^{124}$ SC Res 986 , operative para 8(a) and (b).

125 SC Res 1483 (22 May 2003), operative para 21. This mandate was later renewed through SC Res 1546 (8 June 2004).
} 
of a Governing Council and a Secretariat. In its capacity as a subsidiary organ of the Security Council it enjoys the immunities and privileges of the United Nations. The Trust Fund itself is a distinct legal entity from the Commission and as a result the latter cannot automatically confer by way of right its own legal personality to the Fund. The Trust Fund is certainly subject to the Commission's authority as its appointed trustee. The various escrow accounts (essentially special accounts/trust funds) established by the Security Council since 1991, a significant purpose of which was to funnel money into the Compensation Fund, maintained a particular legal relationship with the Fund. On the one hand they were wholly independent legal entities, while on the other hand they were administered by different trustees; namely the Secretary-General in the case of the escrow accounts set up by Resolutions 706, 712 and 986. Nonetheless, the following question necessarily arises: since all accounts/trust funds were created by the same entity, namely the Security Council, is the transfer of assets from the escrow Funds to the Compensation Fund a self-contract (or self-dealing), or a transaction between two distinct legal entities? The Council may have not paid any attention to this issue and certainly the establishment of separate accounts on the basis of each resolution may signify the rejection of self-dealing a priori. It should be pointed out that the non-existence of a self-contract is not premised on the multiplicity of accounts, but on the ownership of the particular accounts. In the present case the Compensation Fund and the other Council-based escrow accounts were created by the Council and the assets deposited therein are, until their final disbursement, in the ownership of the Council. However, it is also true, on the basis of our discussion, that the Council has endowed all the Funds with some degree of international legal personality and as a result they are capable of contracting in their own name and not solely through that of the Council. ${ }^{126}$ It is also fair to argue that the Council only delegated actual powers as opposed to mere functions. This is true because the Council did not simply delegate to the subsidiary body the authority to implement a particular decision, but conferred upon it authority to make decisions of its own right. ${ }^{127}$ It seems consistent with legal reasoning, therefore, to argue that all relevant transactions do not constitute self-contracts. ${ }^{128}$

Moreover, it is also briefly worth mentioning that in accordance with the Latin maxim delegatus non potest delegare, a delegate cannot delegate his authority to a third entity and this is also true with respect to the powers conferred to subsidiary organs of the Council. ${ }^{129}$ Even if this rule pertains to the institutional law of intergovernmental organisations generally, as well as the Security Council more particularly, it is subject to some exceptions. Such an exception must certainly pertain in respect of those trust instruments that authorise the trustee to carry out his functions through implementing agents, although in most cases these entities will be endowed with the ability to carry out functions rather than take substantive decisions. These exceptions to the non-delegation rule occur less

\footnotetext{
${ }^{126}$ This argument is true notwithstanding the fact that subsidiary organs have not simply been delegated some powers by their creator, but instead they exercise a part of the authority their creators possess under the UN Charter. Advisory Opinion of Awards of Compensation Made by the UN Administrative Tribunal (1954) ICJ Rep 47.

${ }^{127}$ See Meroni v High Authority, Case No 9156, [1958] ECR 133, pp 147-149, in which the ECJ decided that the powers delegated to two subsidiary organs of the High Authority in respect of collecting an iron ore levy on account of the Scrap Equalization Fund entailed a degree of independence to make some decisions. The delegation, therefore, concerned powers and not merely functions.

${ }^{128}$ Self-dealing is strictly prohibited in the international law of trust funds. See J Gold, Trust Funds in International Law: The Contribution of the International Monetary Fund to a Code of Principles, (1978) 72 AJIL 856, p 864. This, however, has not prevented some funds, such as the Prototype Carbon Fund, from describing themselves as trusts.

${ }^{129}$ See D Sarooshi, The United Nations and the Development of Collective Security: The Delegation by the UN Security Council of its VII Powers (Oxford UP, 1999), pp 20ff, where the evidence produced as to the applicability of this rule in international law is mostly theoretical and comparative.
} 
in the context of the United Nations, but are prevalent in respect of trust funds administered by the IBRD on account of the practice encountered in the relevant trust instruments.

A less complicated Council-based trust fund is that established under the terms of Resolution $1177^{130}$ with the purpose of funding the work of and covering the expenses of the Eritrea-Ethiopia Delimitation and Demarcation of Border Commission (UN Border Commission Trust Fund). There is no mention in the reports of the Secretary-General and the Council as to whether the trust fund should be organised as a special account or under more elaborate terms, ${ }^{131}$ but the facts indicate that given the limited mandate and scope of this particular trust fund, the call to the Secretary-General to establish it must certainly fall within the ambit of Council-ordered special accounts. Clearly, depending on the financial size and scope of a projected trust fund, the Council may direct the Secretary-General to establish a fund with the attributes of the Compensation Fund, consisting of a trustee (in the form of a subsidiary body) and an elaborate governance system, or instead opt for a less complicated special account that is to be administered by the Secretary-General and subject to the UN's Financial Regulations and Rules. ${ }^{132}$

\section{Special Accounts and Trust Funds of the UN Secretary-General}

There may well exist some degree of overlap between trust funds (as special accounts) established and operated by the Secretary-General in the exercise of his ordinary functions as administrator of the UN Organisation ${ }^{133}$ and those that are set up by the Secretary-General upon request by the General Assembly. ${ }^{134}$ Where the Secretary-General decides to set up the former type, he must not only ensure that he possesses the requisite discretionary power (or implied authority), but that this must be exercised in good faith. ${ }^{135}$

Examples of trust funds established in the exercise of his ordinary functions include the two funds set up within the Department of Political Affairs, namely the Trust Fund for Preventive Action (TFPA) and the Trust Fund for Special Missions and other Activities related to Preventive Diplomacy and Peacemaking (UN Special Missions Trust Fund). The authority of the Secretary-General to establish these trust funds stems from Article 97 of the UN Charter that relates to the capacity of the Secretary-General as the UN's chief administrative officer. Equally, this authority is also derived explicitly from Regulation 4.13 and Rule 104.3 of the UN's Financial Regulations and Rules and the Secretary-General's own Bulletin on the Establishment and Management of Trust Funds. The governing law of the two trusts is their respective Terms of Reference, which in turn refer to the now-defunct Regulations 6.6 and 6.7 of the UN Financial Regulations. ${ }^{136}$ Both trust funds are administered by the Secretary-General and all contributions thereto are of a voluntary nature.

In this manner, the Secretary-General also established the Trust Fund to Assist States in the Settlement of Disputes through the International Court of Justice. This trust fund was set up unilaterally in 1989 by the Secretary-General following consultations with the

\footnotetext{
${ }^{130}$ SC Res 1177 (26 June 1998), operative para 8.

${ }^{131}$ UN Doc. S/2001/1194 (13 Dec 2001) and UN Doc. S/2001/608 (19 June 2001).

${ }^{132}$ The simplicity of the UN Border Commission Trust Fund poses no legal obstacles to third treaty references, such as the 12 December 2000 Agreement between Ethiopia and Eritrea, Art 4(17) of which directed that in order to defray its expenses, the Commission may accept donations from the Trust Fund.

${ }_{133}$ Art 97, UN Charter.

${ }^{134}$ Art 98, UN Charter.

${ }^{135}$ Peynado v UN Secretary General (UN Administrative Tribunal Decision of 30 Oct 1970), Decision No 138, 47 ILR 356, p 368.

${ }^{136}$ Special Missions Trust Fund, Terms of Reference, s I(1).
} 
President of the ICJ. ${ }^{137}$ The legal basis of the fund, besides Article 97 of the UN Charter, is derived also from Articles 1(1) - on the purposes of the UN - and 33 of the UN Charter, which refers to the various means of dispute settlement among States. ${ }^{138}$ It necessarily follows that in order to promote the ICJ as a forum for the peaceful settlement of disputes, the creation of a trust fund to which developing States would have access to defray the cost of their expenses, squarely fits the purposes and objectives of the Charter and the functions of the Secretary-General. As a result, both the ICJ and the Secretary-General possess implied power to set up a trust fund (besides the Secretariat's powers under the UN's Financial Regulations), as the promotion of peaceful settlement of disputes via the ICJ does not fall within the exclusive competence of any UN principal organ.

In accordance with Article 6 of the Terms of Reference of the ICJ Trust Fund, the Secretary-General is its administrator (trustee). Much like all other UN trust funds this is also subject to the Organisation's Financial Regulations and Rules. Despite the existence of a panel of experts in Article 9 of the Terms of Reference, this entity is not meant to substitute the Secretariat's trustee function. Its role is to provide expert advice with regard to those developing State applicants that merit financing by the fund. ${ }^{139}$ Contributions to the trust fund by potential donors can be made by bank transfer or by cheque. ${ }^{140}$ There are situations where the Secretary-General is requested by either the Assembly or the Council to set up a nonelaborate trust fund in the form of a special account. In this case the Secretary-General is acting under Article 98 of the Charter, as well as in accordance with UN Financial Regulation 4.13, and for all practical purposes it is the Assembly that must justify the establishment of the fund through its implied powers. ${ }^{141}$ A notable example is the International Tribunal for the Law of the Sea (ITLOS) Trust Fund, created by the Secretariat following a request by the General Assembly. ${ }^{142}$ In the Terms of Reference of the ITLOS Trust Fund, the Assembly's implied powers were confirmed on the basis of Article 287 of the UN Convention on the Law of the Sea (UNCLOS), ${ }^{143}$ which much like the relevant provisions of the UN Charter exhort States to settle their disputes through ITLOS. ${ }^{144}$ An additional reason was the establishment by the Secretary-General of a similar fund for the ICJ. ${ }^{145}$ Although the primary legal basis for the establishment of the ITLOS Trust Fund was the institutional act of the UN Secretariat, the Agreement on Cooperation and Relationship between the UN and ITLOS provided the grease

\footnotetext{
${ }^{137}$ UN Doc. A/44/PV.43 (1989), pp 7-11; see Report of the ICJ on the Secretary-General's Trust Fund, UN Doc. A/47/444 (7 Oct 1992), Annex, Terms of Reference of the ICJ Trust Fund.

${ }^{138}$ P H F Bekker, International Legal Aid in Practice: The ICJ Trust Fund, (1993) 87 AJIL 659, p 661; besides the establishment of the ITLOS Trust Fund, the Permanent Court of Arbitration set up in 1995 its own Financial Assistance Fund as a means of promoting peaceful dispute settlement. See ILAAB Committee on Transnational Dispute Resolution, A Study and Evaluation of the UN Secretary-General's Trust Fund to Assist States in the Settlement of Disputes through the ICJ, reprinted in (2002) 2 Chinese JIL 234, pp 250-53.

${ }^{139}$ Equally so in the case of the ITLOS Trust Fund Terms of Reference, Art 8. Some authors argue that one of the reasons why developing countries have been denied access to international justice relates to cost. Hence, trust funds that help defray such costs enhance the pursuit of international justice. See C Claypoole, Access to International Justice: A Review of the Trust Funds Available for Law of the Sea-Related Disputes, (2008) 23 Int'l J Marine \& Coastal L 77.

${ }_{140}$ Report of the SG on the ICJ Trust Fund, UN Doc. A/59/372 (21 Sep 2004).

141 This requirement is raised, albeit in cursory and unclear terms, by UN Financial Regulation 4.14, which states that "the purpose and limits of each trust fund and special account shall be clearly defined by the appropriate authority".

${ }^{142}$ GA Res 55/7 (27 Feb 2001), operative paras 9 and 10. In operative para 45 an additional request was made for the establishment of a second trust fund with the aim of assisting developing and small-island States in attending the meetings of the consultative process (Annex II to GA Res 55/7).

1431833 U.N.T.S. 3.

${ }^{144}$ ITLOS Trust Fund Terms of Reference, Art 1(1), Annex I to GA Res 55/7.

${ }^{145}$ Id, Art 1(2).
} 
in the wheels of the Fund. ${ }^{146}$ Article 10 of the Agreement exhorts the parties to collaborate as far as practicably possible in order to achieve coordination and uniformity in their financial and administrative operations, albeit without making any reference to the trust fund. The Agreement between the two entities, although itself not a decisive criterion for the existence of the Trust Fund, is significant because it demonstrates that some aspects of collaboration of entities within the UN system is not always straightforward enough to be settled through Assembly resolutions or the utilisation of implied or other powers. ${ }^{147}$

\section{Ownership of the Trust's Assets}

When Joseph Gold was discussing in his 1978 article the issue of ownership over the assets of a trust fund he was referring to the IMF as a trust entity that is administered by the IMF as a trustee. He had no problem, therefore, concluding that the IMF as trustee possessed rights of ownership over the Fund's resources, albeit in a manner that these are clearly divisible between the trustee and the beneficiaries. ${ }^{148}$ Unlike the absence of equitable beneficiary rights in respect of intergovernmental trust funds, the IMF's beneficiaries are the States parties to its Articles of Agreement. This constitutes, therefore, an exception to the general rule, according to which named beneficiaries are absent from the administration/donor agreements. There is no specific mention to ownership in the World Bank's trust funds operational policies, or the Financial Regulations of the UN and the UNDP. However, it should be recognised as a general principle of, at least, the domestic law concept of trusts that trust ownership of the trust's assets passes to the trustee upon appointment and transfer. ${ }^{149}$ This is a special type of ownership and although it is beyond the purview and expertise of this book to discuss the legal nature of this type of ownership in its domestic setting, it is essentially an ownership of assets held in trust. That is, the trustee is their legal owner until such time, and under the terms of the trust instrument - or the trustee's discretion, whatever the case may be - that the trustee disburses the trust's assets to the intended beneficiaries. It is an inherent operation in the law of trusts that the trustee is the ipso facto owner (in trust) of the trust's assets. Adversely, in an agency relationship, the agent (equivalent to the trustee in a trust relationship) would not normally come to own the funds given him by the appointing party, unless this was the express intention of the parties. ${ }^{150}$ A significant advantage in a trust ownership of assets is that in case of liquidation of the property and assets of the trustee, that which is held in trust may not be subjected to liquidation in order to satisfy the trustee's creditors.

The application of this general principle to trust funds established under international law seems sensible in terms of current legal practice and also for practical reasons. The operation of an intergovernmental trust fund typically commences from the moment the first donor transfers his contribution to the designated commercial bank account - although even prior to this event the entity of the trust fund will generally have come into existence. This account will have been credited to the trustee under his name or under the name of the

\footnotetext{
${ }^{146}$ GA Res 52/251 (8 Sep 1999), Annex.

${ }^{147}$ In contrast, the Trust Fund for the Caribbean Court of Justice was established solely pursuant to Art II of the 2004 Revised Agreement Establishing the Court's Trust Fund, to which all CARICOM member States appended their ratification. The text of the Agreement is available at: <http://www.caricom.org/jsp/secretariat/legal_instruments/ccj_revisedtrustfund.jsp>.

${ }^{148}$ Gold, supra note 128 , p 863.

149 South West Africa cases, Separate Opinion of Judge McNair, supra note 4, (1950) ICJ Rep 146, p 149.

${ }^{150}$ Generally, in the common law the principal's property may only come to the possession, and not the ownership, of the agent, where the principal has failed to meet his obligations to the agent. B S Markesinis, R J C Munday, An Outline of the Law of Agency (Butterworths, 1979), pp 111-12.
} 
particular trust and intended that it be held under the particular ownership of the trustee. In the case of tangible assets, particularly money and monetary instruments, one cannot talk of their transfer from one entity to another in terms other than ownership being passed to the transferee. It may be, of course, that the transferor wishes such ownership to persist for a specified duration or for a particular purpose; such ownership of assets will, therefore, be conditional. The same conditional nature is applicable to money held in trust by trustees appointed by a treaty, if this indeed represents the wish of the donors.

The practice of a good number of trust instruments and administration agreements indicates that contracting parties expressly acknowledge this general principle of ownership in their trust relationship, other than by common understanding. Two types of trustee ownership are described in the various instruments. The first comprises those in which the trustee is authorised to establish an account in his name and which is to be credited to the trustee and designated as such. This represents the practice of IMF trust instruments and a standard clause is generally employed. ${ }^{151}$ The other type consists of clauses in the trust's terms of reference or in the administration agreement whereby the trustee is named "legal owner [and in that capacity shall] hold in trust the funds, assets and receipts which constitute the Fund" ${ }^{152}$ Whether or not the matter of ownership is specifically described or implied in a trust or other instrument, it must be taken for granted that if it is the intention of the parties to establish a trust fund then ownership of monetary assets belonging to the trust entity passes to the trustee. The same is generally true with regard to non-monetary assets, such as supplies, equipment and other property that belongs to the trust fund. ${ }^{153}$

At least two significant issues arise as a result of the trustee assuming ownership of the fund's resources. The first concerns the very status of ownership itself once the fund instrument's life cycle comes to an end, or indeed when it is terminated by anyone of the parties. As a general rule, administration agreements contain a termination clause with an end date for the project that is subject to renewal upon written agreement between the parties. Termination clauses, moreover, stipulate that any remaining trust fund assets, including accrued investment income, shall be returned to the donors on a pro rata basis within a particular time frame following termination. ${ }^{154}$ Equally, unless otherwise agreed by the parties, in the event of early termination any agreement entered into by third parties and the trustee, particularly where the trustee is an international development bank, shall not be legally affected. ${ }^{155}$ The other major issue concerns the protection of the trust fund's property against third parties. This is one of the most significant reasons for the use of the trust model in which the trustee is generally an intergovernmental organisation, whether an international development bank, such as the World Bank, or a specialised UN agency. From the moment the trust fund's resources pass into the ownership of the trustee, said resources are not subject to taxation, ${ }^{156}$ in accordance with the respective Headquarters Agreement entered into by the Organisation and the host State. This privilege could be further extended to encompass all those States with whom said Organisation/trustee has an agreement that precludes it from paying tax. Apart from tax and other privileges the trust's resources, now forming an integral part of the Organisation's self-owned resources, enjoy the immunities of that entity in full, subject to this author's reservations on abusive intergovernmental trust arrangements. Although this most probably constitutes a logical implication with regard to the extension of

\footnotetext{
${ }^{151}$ See, e.g., s IV(c)(i), Instrument to Establish the MDRI-I Trust, supra note 87.

152 GEF Instrument, supra note 34, Annex B, Art 1.

${ }^{153}$ Art V, UNDP-Italy Trust Fund Agreement for Anti-Poverty Partnership Initiatives (27 June 2000).

${ }^{154}$ E.g., Art 15(a) of the Denmark-IBRD Agreement for the ASEM-EU Asian Financial Crisis Response Fund, Project No TF020147 (10 Nov 1998).

155 Id, Art 15(b).

${ }^{156}$ Rule 104.49(a), UN Financial Regulations.
} 
the trustee's immunity, a good number of administration agreements and trust terms of reference specifically incorporate the extension of such immunity over the assets of the administered trust. ${ }^{157}$ It may be argued that by doing so and subjecting trust resources to the immunities and privileged regime of the international financial institution that is acting as trustee in fact constitutes an abuse of that entity's powers. This criticism is only valid where the founding treaty of the trustee does not give rise to an explicit or implied power to set up trust funds and where, moreover, it does not subject the ownership of their resources to the trustee. ${ }^{158}$ This author is not aware of any such express limitations. In any event, such immunity is by no means unrestricted and is limited only to public acts of the organisation (jure imperii), at least in the particular case of the IBRD. ${ }^{159}$

There is perhaps a single exception to the trust ownership rule. This involves the IMF's Heavily Indebted Poor Countries (HIPC) and the Multilateral Debt Relief Initiative (MDRI) trust funds and particularly the practice of donors (creditors) therein to absolve debt through the conclusion of bilateral agreements with the beneficiaries (debtors). In such cases, the debt is not transferred or sold to the trustee by the creditors and as a result the trustee does not hold it as an asset on behalf of the donors.

On the basis of the aforementioned consistency in the practice of States through their donor agreements with international organisations acting as trustees, these principles must be deemed as having passed beyond any doubt into the realm of customary international law. This includes the principle that trust assets are in the trust ownership of the trustee and that they are covered by his privileges and immunities. ${ }^{160}$

\section{Liabilities of Intergovernmental Trusts}

The notion of liability concerns the relationship of an entity with both its contracting counterparts and those third parties that have suffered from an unlawful act, or a debt, which was caused by an act or omission that may be attributed directly or indirectly to the said entity. In international law the attribution of liability is connected with the activities of actors possessing a substantial degree of international legal personality; thus, States and full international organisations. Customary law suggests that whereas the existence of damage is not a necessary ingredient in the attribution of State or international organisation responsibility, an unlawful act certainly is, when committed by the organs of said entity or its

\footnotetext{
${ }^{157}$ Art 13, GEF Instrument, Annex B, supra note 34, encompasses within the trustee's (World Bank) privileges and immunities regime, besides property, assets and income, also the GEF's archives, operations and transactions; see Art 105, UN Charter; Art VII(4), IBRD Articles of Agreement; Art VIII(4), IDA Articles of Agreement; Art IX(4), IMF Articles of Agreement.

158 The UN Charter and the World Bank's Articles of Agreement provide the two entities with only implied powers to set up trust funds, whereas Art 8 of the 1963 Khartoum Agreement Establishing the African Development Bank, 1276 U.N.T.S 3 (as amended on 7 May 1982), provides an explicit power. Explicit powers are more common in post-1980 instruments.

${ }^{159}$ Lutcher SA e Papel Candor v IDB, (1967) 42 ILR 138.

160 The principle of trust ownership is also discernible in those rare cases where the trustee is a private fund manager, as opposed to an international legal person. This is the case, for example, with regard to the Marshall Islands Nuclear Claims Fund, established in accordance with the 1986 US-Marshall Islands Agreement for the Implementation of Section 177 of the Compact of Free Association. Therein, the private nature of the trustee is counter-balanced with the exemption of all taxes by the two States in respect of compensations (Arts I(2)(b) and $\mathrm{V}(1)$ and (2)). Moreover, the fact that the government of the Marshall Islands has no ownership of the Fund's assets is also attested by the eventuality of the Fund winding down its operations, in which case the remainder of the capital is to be distributed to the Marshall Islands.
} 
designated agents. ${ }^{161}$ The enjoyment of immunity by actors possessing full international legal personality does not necessarily extinguish their liability where an internationally unlawful act has taken place, nor obviously where they have incurred a debt; rather, it may serve to restrict in certain cases the impeachment of those actors before national courts, but only under particular circumstances and in respect of particular forms of liability. The underlying principle regarding the liability of international organisations is that where responsibility is in fact incurred by the legal person it is not shared by those members that set up the organisation in the first place. This principle was clearly advocated in the complex Tin Council litigations, which concerned the debts of the International Tin Council, a full international organisation with headquarters in London, against private debtors at a time when the organisation itself had financially collapsed and was in the process of liquidation. The creditors turned to the International Tin Council's member States for the outstanding debts, but ultimately the House of Lords affirmed that the Council possessed a personality that was distinct from that of its members and that consequently the contractual obligations assumed by the Council did not give rise to liability of its constituent member States, which were viewed as non-parties to the transactions of the Tin Council. ${ }^{162}$ As a result of their third party nature the International Tin Council's member States could not be held liable for the debts that the Council itself had incurred on account of its operations.

The international law pertinent to the liability of international organisations is relevant only in certain respects to intergovernmental trusts. Firstly, few trusts enjoy a distinct international legal personality, let alone the status of international organisations; secondly, the law under discussion was developed to deal only with such organisations. These are the apparent limitations. Nonetheless, the parties to intergovernmental trusts are generally concerned about their personal liability and not about that of the trust entity and it is exactly this type of liability that they attempt to extinguish through the trust paradigm. Finally, in the absence of any concrete rules applicable to the liability of intergovernmental trusts, the law relating to international organisations may be employed by reason of analogy. ${ }^{163}$ Moreover, given that the trustees to intergovernmental trusts are typically international organisations, to which all contractual powers have been granted, the liabilities of the trustee and the trust will readily be subjected to general international law. The following paragraphs of this section attempt to explore the liability of trust entities on the basis of their legal organisation and degree of legal personality.

In the case of trust funds that possess full international legal personality this principle is sometimes highlighted in the trusts' constitutional documents. Article 6 of the Agreement Establishing the Common Fund for Commodities (CFC), itself a trust fund, ${ }^{164}$ states that "no member shall be liable, by reason only of its membership, for acts or obligations of the

${ }^{161}$ B Graefrath, Responsibility and Damages Caused: Relationship between Responsibility and Damages 185 (1984-II) RCADI 1, pp 34ff. See also ILC Commentary on Articles on State Responsibility, (2001) YB ILC vol II (Part II), p 56.

${ }_{162}$ J H Rayner (Mincing Lane) Ltd v Department of Trade and Industry and Others and related appeals; MacLaine Watson \& Co Ltd v Department of Trade and Industry; MacLaine Watson \& Co Ltd v International Tin Council (judgment of 26 Oct 1989), 81 ILR 670, per Lord Templeman, p 678. These will be referred to as the International Tin Council cases.

${ }^{163}$ In fact, the ILC Rapporteur on the Responsibility of International Organisations commented that the ICJ's approach in the Lagrand case (Germany v USA), Judgment, (2001) ICJ Rep, para 77, according to which individuals are also subjects of international law may lead the Court to assert the legal personality also of nongovernmental organisations. J Gaja, First Report on Responsibility of International Organisations, UN Doc A/CN.4/532 (26 March 2003), p 9. This is particularly important in respect of the majority of intergovernmental funds that lack a distinct legal personality.

${ }_{164} 1538$ U.N.T.S. 3. Besides the CFC there exist numerous agreements on particular commodities, such as sugar, coffee, metals and others. See J E S Fawcett, The Function of Law in Commodity Agreements, (1970) 44 BYIL 157. 
Fund". This is certainly not a declaration of full, but only partial, absolution from liability, which no doubt supports the theory of secondary member-State responsibility. This line of thinking suggests that the injured party must first present its claim against the organisation to the legal person of that organisation and only proceed against its member States where the organisation was in default in providing an adequate remedy. ${ }^{165}$ This view (i.e. that the creditors can turn against the constituent members in the second instance) was also expressed in terms of satisfying the dictates of justice and substantive fairness by some of the Lords in the Tin Council cases, ${ }^{166}$ but whereas its ethical dimension is doubtless its legal foundation and juridical substantiation is uncertain, albeit it is certainly plausible under particular circumstances. ${ }^{167}$ The wording of Article 6 of the CFC Agreement suggests that its member States may in fact suffer liability if by their individual action they commit an unlawful act or incur a debt which is attributable to the CFC. ${ }^{168}$ It is open to interpretation whether a member State may be additionally liable for the debts or other liabilities of the organisation, ${ }^{169}$ absent an unlawful act or omission on its part. The answer in the specific case must be negative, because attribution of liability to a member State without the element of fault presupposes the existence of liability on the basis of membership alone, which is negated in Article 6 of the CFC Agreement.

In both the Tin Council cases and the Westland Helicopters case ${ }^{170}$ the incorporation or not of a limitation of liability clause was considered central to the question of separate member State liability. Nonetheless, although none of the two organisations possessed such a clause in their respective treaties, neither the House of Lords nor the Swiss Federal Supreme Court entertained the notion that the constituent States of an organisation may be liable for the debts and liabilities of the international legal person. ${ }^{171}$

In the context of domestic law, a contractual undertaking between a trust fund organised in the form of an international organisation and a private party would be subject to private law, save for the trust's immunity from jurisdiction and the separate liability of the trust's member States, which are matters clearly governed by international law. Hence, whereas the constitutive treaty of a trust fund that absolves members of separate liability is applicable vis-à-vis the trust's contractual undertakings with private parties, a clause in the treaty the effect of which is to limit the trust's liability generally (i.e. the liability of the legal person of the trust alone) would have to be assessed in accordance with the domestic law of

165 See M Hirsch, The Responsibility of International Organisations Towards Third Parties: Some Basic Principles (Dordrecht, 1995), pp 155ff.

${ }^{166}$ HL Tin Council cases, supra note 162, per Lord Griffiths, p 683.

167 Some authors have convincingly argued that the member States of an international organisation may be separately sued in respect of that organisation's liability where the organisation was created for their personal benefit and they were additionally negligent in the supervision of its activities. Thus, member States would be liable under general principles of State responsibility as having themselves committed an internationally wrongful act, apart from the organisation. See R Sadurska, C M Chinkin, The Collapse of the International Tin Council: A Case of State Responsibility? (1990) 30 Va J Int'l L 845.

${ }^{168}$ According to Art 32(1) of the CFC Agreement, member States are liable to the Fund for failure to make their payments and meet their other financial obligations. Where, therefore, such an eventuality occurs and the CFC incurs a debt towards a third party it is plausible, although not wholly clear, to assume that said third party will have a valid cause of action against the defaulting CFC member State. One should not make a meal out of this! In every case, the third party will have to demonstrate the existence of an unlawful act directly attributable to the individual member State.

${ }^{169}$ In EC Parliament $v$ Council, Case C-316/91, (1994) ECR-I 625, p 661, the ECJ pointed out that in the implementation of the commitments undertaken by the EC in the context of Lome Convention IV, (1990) 29 I.L.M. 783, it is jointly liable alongside its member States.

${ }^{170}$ Westland Helicopters Ltd v Arab Organisation for Industrialisation (AOI), UAE, Kingdom of Saudi Arabia, State of Qatar, Egypt and Arab-British Helicopter Company, (International Chamber of Commerce arbitration award of 5 March 1984), 80 ILR 600.

${ }^{171}$ AOI and Others $v$ Westland Helicopters Ltd, Judgment of 19 July 1988, 80 ILR 652. 
the State where the transaction took place, or the locus of the headquarters of the organisation. It is, however, doubtful that any jurisdiction would be willing to absolve an international organisation for all its privately incurred debts.

In the case of a quasi-international organisation, such as the Global Fund for AIDS, TB and Malaria, the situation is different. Although the Swiss government conferred international legal personality to the Global Fund through their respective HQ Agreement, Article 5 of said Agreement exempted from immunity of legal process, inter alia, "counter claims directly related to principal proceedings initiated by the Fund", arbitration awards between itself and Switzerland, as well as "disputes arising out of contracts and disputes of a private law character to which the Global Fund is a party" ${ }^{172}$ Moreover, in an independent legal opinion delivered under instructions from the Fund by expert counsel in Swiss civil law, it was noted that the status of the Fund as a foundation under the Swiss Civil Code entailed its liability towards third parties in the same manner as any other Swiss private foundation, ${ }^{173}$ while its registration with the Trade Register rendered it subject to potential bankruptcy proceedings. ${ }^{174}$ Furthermore, in accordance with the Swiss Civil Code "an individual member of the [Fund] would incur a personal liability for torts only if it were established that such individual, acting purposely or by negligence, infringed personally a provision of law or violated an absolute right of a third person, and in doing so, caused damages". ${ }^{175}$ This provision refers to physical persons and is not applicable to States that are parties to the Global Fund. Given that the Fund is not an international organisation and that therefore its member States cannot hide behind a corporate veil, any unlawful act caused, or debt incurred, by them will trigger the responsibility of that State and possibly the civil liability of the Fund. It is clear that the financial resources and other assets of the Global Fund that are held by its trustee, the IBRD, cannot be made the subject of private legal proceedings because on the basis of the trust agreement with the IBRD ownership of the assets has passed to the World Bank. Moreover, it is self-evident that the Global Fund will be amenable to civil proceedings as a legal entity, as well as separately through anyone of its members or personnel, in countries outside Switzerland, depending on the laws of those countries, unless the Fund enters into HQ or other agreements to the contrary. ${ }^{176}$

The liability of trust funds incorporated as limited international organisations is prescribed by their constitutional treaty, their HQ Agreement and general international law. The 1992 Convention establishing the International Fund for Compensation for Oil Pollution

\footnotetext{
${ }^{172}$ Art 25(1), Agreement between the Swiss Federal Council and the Global Fund in View of Determining the Legal Status of the Global Fund in Switzerland, GF Doc. GF/B8/7, Annex 4a [Global Fund-Switzerland HQ Agreement]. The nature of the HQ Agreement only confers international organisation-like status to said entity in the country where this is granted. Switzerland has a strong tradition of conferring such status to particular NGOs operating therein on the basis of its Federal Decree of 30 September 1955 On the Conclusion and Modification of Agreements with International Organisations in View of Determining their Legal Status in Switzerland. Similar agreements have been concluded with the International Olympic Committee (IOC), the International Air Transport Association (IATA) and others. See Legal Opinion of M C Krafft, On the Modifications which should be Made to the Legal Status of the Global Fund in View of the Transformation of the Fund into an Intergovernmental Organisation, GF Doc. GF/B5/Annex 6.1, pp 11-15.

${ }^{173}$ Arts 55, 80 Swiss Civil Code (CC), cited in D Hempel, Memorandum on the Liability of the Foundation and the Personal Liability of its Bodies Members (25 March 2003, on file with author), p 6.

${ }_{174}$ Art 39(12) Federal Statute on Debt Collection and Bankruptcy, cited id, pp 7-8.

${ }^{175}$ Arts 55 CC and 41 of the Swiss Code of Obligation. Cited id, pp 9-10.

${ }^{176}$ Although the establishment of an international organisation and its subsequent international legal personality is generally considered a matter of fact, some States take the view that the absence of a distinct HQ or other agreement does not oblige them to grant immunity or other privileges to an organisation. See Communauté économique des Etats de l'Afrique de l'Ouest and Others v Bank of Credit and Commerce International, (1993) 120 Journal du Droit Int'1 353, p 357.
} 
Damage (IOPCF) ${ }^{177}$ makes no mention to the Fund's liability as a purported "international organisation", apart from the obligation of the Fund to compensate victims for oil spills caused by its members and then only on their behalf and not with its own assets. ${ }^{178}$ The only reference to liability is found in Articles 5 and 23(a) of the Fund's HQ Agreement with the UK, which on the basis of customary international law provides no exemptions from liability in respect of the Fund's contractual undertakings or civil wrongs. Headquarters Agreements can significantly limit or expand the ambit of the trust's range of liabilities. ${ }^{179}$

Trust accounts (i.e. trusts organised very simply around a bank account and lacking other organisational structures) and trust funds established under the implied powers of an organ within an international organisation and lacking an independent legal personality are incapable of assuming liabilities under both domestic and international law. While for accounting purposes they will be considered as distinct from the other accounts administered by their trustee or administrative agent, any debts incurred as a result of their management will be subsumed within the general liability of the administering authority (which is highly unlikely), unless the trustee has incurred the debts and liabilities in the name of the trust fund. In practice, the trustee will generally contract in the name of the trust account and all liabilities will be debited thereto until the depletion of its assets.

The trustee will be responsible to the donors and the trust for the fulfilment of the tasks entrusted upon him. The law applicable to assess said liability will rarely, if at all, be defined in the trust or donor agreements, but given the treaty character of the majority of such agreements it is fair to assume that the process of liability will be governed by international law. Where the trust fund or the donor is not a State or an international organisation the law governing liability will usually be that of the seat of the trustee. The trustee will seek invariably to insert standardised limitation of liability clauses in the relevant agreements, but depending on the amounts of committed assets this type of clause will not always be acceptable to the trust or the donor. In the case of the World Bank, reference will be made by the Bank to the provisions of its relevant operational manuals given that it is unable to violate

\footnotetext{
177 Cmnd 2658.

${ }^{178}$ Art 7(1), 1992 IOPCF Convention. As Gavouneli points out it was adamantly clear from the deliberations of the predecessors to this convention that not only was the liability of the relevant State not to be implicated, but that member States were not even obliged to provide guarantees. As a result, even before the conventions were concluded the oil industry covered the lacuna with two private insurance agreements that provided for limited compensation. The first of these was the Tanker Owners Voluntary Agreement Concerning Liability for Oil Pollution (TOVALOP), which was complemented by the Contract Regarding an Interim Supplement to Tanker Liability for Oil Pollution (CRISTAL). These have obviously subsequently been revised. See M Gavouneli, Pollution from Offshore Installations (Graham \& Trotman, 1995), p 117.

${ }^{179}$ In United States Lines Inc $v$ WHO, (1993) 107 ILR 182, a private corporation sued the WHO in Manila in respect of a contractual undertaking. The Intermediate Appellate Court of Manila held that absent a waiver the WHO continued to enjoy absolute immunity in the Philippines and that the mere presence of the Organisation's representatives at trial was in order to assert its immunity. Equally, the WHO's immunity was found to persist not only from its 1951 WHO-Philippines HQ Agreement, but also from the 1947 Convention on the Privileges and Immunities of the Specialised Agencies of the United Nations. In Mukoro v EBRD, (1994) 107 ILR 604, the plaintiff sued the EBRD on the basis of racial discrimination. The 1990 Paris Agreement Establishing the EBRD, (1990) 29 ILM 1077, had conferred immunity upon its employees and officers, but not the legal person of the EBRD. By virtue of a 1991 Order in Council, immunity was subsequently conferred on the EBRD in respect of acts done within the scope of its official activities. The London Employment Appeals Tribunal held that official activities included, among others, the EBRD's administrative activities. In 1991 the EBRD and the UK concluded an HQ Agreement that granted the EBRD general immunities. This result was confirmed by the Tribunal, which held that staff selection by the EBRD fell within the prescribed range of administrative activities. Id, Mukoro judgment, pp 611-12.
} 
or circumvent its own institutional law. ${ }^{180}$ International financial institutions when acting as trustees employ the "same duty of care [to their own affairs]" standard, ${ }^{181}$ but occasionally they have to use more extensive language to limit their potential liability. By way of example, Article 9 of the Agreement between the Kreditanstalt fur Wiederaufbau and the IBRD/IDA concerning the German Consultant Trust Fund stipulates among others that the Bank "shall not be subject to any other duties or responsibilities to the donor, including, without limitation, any duties or obligations that might otherwise apply to a fiduciary or trustee under general principles of trust or fiduciary law". ${ }^{182}$ Given that this agreement envisaged from its very title the formation of a trust vehicle, the renunciation of fiduciary or trustee obligations by the Bank is at odds with its contractual undertaking.

It is not only the trustee that may choose to absolve himself of prospective liabilities through his agreement with the donor, but also the donor himself. This observation is particularly significant in light of trust accounts that do not possess any independent legal personality and thus any liability in respect of their assets is to be found in the agreements between the donor(s) and the trustee. Article 8(2) of the Denmark/IBRD ASEM-EU Asian Financial Crisis Response Fund states that:

Otherwise than for failure to perform its obligations set forth in this Agreement, the Donor will not under any circumstances whatever be liable for damages caused either to the Bank or third parties during the performance of this Agreement. No claim can be submitted to the Donor for compensation or for restoration of any such damage or loss. 183

In the case of trust funds the implementation of whose objectives befalls a number of entities, all of which possess international legal personality, the parties involved may seek to limit their general liability by expressly stating that none is the agent of the other and that each party is liable for his own actions - absent contributory acts or omissions. ${ }^{184}$

I will not be addressing in this article the issue of the trust's immunity, principally because this matter will be subsumed under the immunities of the trustee, where the trust does not have a distinct obligation from that of the trustee. What, however, remains unclear is the ascertainment of the public (jure imperii) or commercial (jure gestionis) nature of the trust or the trustee's act in each case. Ordinarily, given that the very purpose of the trusts surveyed in this article is to fulfil a charitable or humanitarian objective, all their undertakings should be viewed as public acts. This approach, however, fails to take into account the following factors: a) the trustee receives a commission for his services; b) the trustee is required to invest the trust's assets; c) the donors may expect to receive a commercial benefit from the operations of the trust, such as credits under the UNFCC's Clean Development Mechanism. Academic opinion and judicial developments seem to favour distinguishing between the public and private acts of international organisations, albeit the view is not unanimous. ${ }^{185}$ Although neat analogies are incompatible with the nature of trust funds, it is not without merit to argue that on account of the fact that the trustee is an

\footnotetext{
${ }^{180}$ Operational Manual on Trust Funds, BP-14.40 (Jan 1997), s 8(a), which states that "the Bank exercises the same care in the discharge of its functions under the Agreement as it exercises in its own affairs and assumes no further liability to the donor". See also Operational Policy OP-14.40 (Jan 1997), supra note 30, s 9.

${ }^{181}$ See Art 3(6) of the Model Agreement for the Establishment of the Anti-Corruption Activities Fund under the Inter-American Development Bank, contained in IDB Doc CC-6146 (26 Feb 2007).

182 TF 050666 (30 June 2002).

183 TF 020147 (10 Nov 1998).

${ }^{184}$ MoU between Participating UN Organisations, the UN Resident Coordinator and the UNDP regarding the Operational Aspects of the ONE UN Fund for Tanzania (25 Oct 2007), Arts I(4) and IV(4).

${ }^{185}$ See FAO v Colagrossi, 101 ILR 393; Nacci v Bari Institute of the International Centre for Advanced Mediterranean Agronomic Studies, 114 ILR 540.
} 
international organisation or because the trust moreover operates through a complex governance mechanism the same principles should apply mutatis mutantis to trust funds. The complexity of the matter requires much more rigorous analysis than I can offer in this section.

\section{The Donors' Personal Liability: A Challenge to the Contractual Orthodoxy}

One of the principal reasons for setting up trust funds, rather than making direct unilateral monetary contributions, is the intention by the donors to limit all liability arising as a result of an activity that entails the provision of financial assistance to development or other projects worldwide. It is true that a donor could, in the case of bilateral assistance agreements, limit the range of his liability by introducing an appropriate clause therein, but this does not mean that the donor is free from all liability where other rules of State responsibility of a peremptory character come into operation. For example, if a donor were to establish a power plant in a developing State that is subsequently found to be faulty (assuming this was known to the donor from the outset and hidden from the recipient State) and which pollutes the waterways of that State, as well as those of its neighbours, the limitation clause in the bilateral agreement will not shield the donor from assuming liability. This liability is extracontractual and can be claimed not only by the "assisted" target State, but also from all other States that have sustained harm as a result of the relevant injury - although evidence of harm is not necessary for the purposes of State responsibility. It is certainly interesting that the presumption among developed States that contribute financial resources as donors to intergovernmental trust funds is that as a result of the express or implicit limitation clause in the donor agreements they can never incur any liability from the operations of the trust fund. This presumption must necessarily be premised on the particular understanding that the intergovernmental trust model excludes the contributing States from all liability, in a way that is akin to the exclusion of liability in respect of member States to international organisations. Nonetheless, this assumption has never been tested in practice and there is no valid justification for approximating the liability of trust donors to that of international organisations' member States. The main reason for this conclusion is that international organisations enjoy distinct international legal personality from that of their members, whereas the vast majority of intergovernmental trust funds do not. ${ }^{186}$ It should be noted that none of the provisions in the ILC's Articles on State Responsibility clearly encompass the liability of the donors for unlawful acts committed by the trust or the trustee. To do so, the Articles would have had to cater for situations where an international organisation, or other entity, commits an internationally wrongful act at the behest of a State without itself being an agent of that State. ${ }^{187}$ Thus, Articles 55 and 57 of the ILC's Articles apply as a residual clause, according to which other general international law will govern cases not covered by them.

The fact that the assets of the trust fund are subsumed under the legal personality of the UN or the World Bank only serves to shield those assets, but this does not mean that the

\footnotetext{
${ }^{186}$ Interestingly, the ICJ in its Preliminary Objections Judgment of 26 June 1992 in the Certain Phosphate Lands in Nauru case, para 47, supra note 17, held that the administering authority for Nauru that was composed of the three trustees (UK, Australia and New Zealand) did not enjoy an international legal personality that was distinct from the three appointing States.

${ }^{187}$ The ILC's Commentary to its Articles on State Responsibility, which concern conduct directed or controlled by the State (Art 8), require that the controlled or directed entity be an agent of the State, which is naturally inapplicable to the intergovernmental trust paradigm. The provision moreover is inapplicable to entities established by multilateral agreement between international legal persons, as is the case with trust funds. See YB ILC, 2001, vol II, Part II, pp 47-49.
} 
distinct legal person of the trustee also shields the donors from liability. Certainly, if, on the basis of global consent, a rule of customary international law were to be borne, which, served to remove all subsequent liability from donors to intergovernmental trust funds, this would negate my aforementioned conclusion under the lex posterior rule. This author is of the opinion that while a customary rule that negates donor liability is beginning to crystallise, it is not of a nature that excludes all liability from the person of the donor, nor of course of the trustee. Simply put, express or implicit limitation clauses in trust agreements protect the donor to the extent that his financial contribution is not knowingly provided for an unlawful purpose and where his agreement with the trustee and any implementing agency equally does not give rise to an unlawful act. ${ }^{188}$ It is taken for granted in every case that the recipient beneficiary accepts the limitation clause in the trust agreement by means of its consent of the grant agreement with the trustee, irrespective of whether this is in the form of a treaty or a MoU.

There are situations in which the donor State and the trustee can never claim to be free from liability as a result of the trust's operations. ${ }^{189}$ Here, I shall mention two situations, but it is not improbable that there are more. The first concerns those situations in which the donor has not only deposited his financial contribution with the trustee, but has moreover engaged himself actively in the operations of the trust by participating in its decision-making body. In those cases where the trust in question is not an intergovernmental organisation the participation of the donor in the executive organ of the trust vehicle entails potential liability that may be satisfied not only from the assets and property of the trust, but also from the assets of the donor. It would defy all notions of justice were the donor to possess executive authority in respect of a fund that is devoid of international legal personality and yet bear no liability whatsoever for acts that are intentionally and manifestly unlawful. ${ }^{190}$ This would certainly constitute a gross abuse of the trust vehicle and it is wholly unlikely that the emerging customary international law of trust funds has permitted such an exception to the general rule of State responsibility. The second situation that gives rise to the donor's

\footnotetext{
${ }^{188}$ The donor would be ethically repugnant were he to commit resources to a developing State through a trust in the knowledge that the money committed or the project financed only benefited the donor himself. This possibility would also arise in respect of emissions trading projects that benefit solely a corporation of the donor, or earmarked donations that are linked to the donor's contractors. It is the contention of this author that in such cases the liability of the donor should be sustained on account of the abuse of the trust vehicle, despite the fact that the acts in question are not unlawful per se. Theoretically, the abuse of the trust vehicle could be considered an unlawful act if it is viewed as a violation of: a) the trust's particular terms under its founding instrument or the donor agreement; b) the general principles of intergovernmental trust law, or; c) the convention under which the trust vehicle was set up. Thus, in respect of a trading emissions project this would entail the violation of the Clean Development Mechanism (CDM) provisions of the 1997 Kyoto Protocol to the UN Framework Convention on Climate Change, (1997) 37 ILM 22.

${ }^{189}$ Draft Art 8(1) of the ILC's Articles on the Responsibility of International Organisations points out that an organisation is in breach of an international obligation when one of its acts "is not in conformity with what is required of it by that obligation, regardless of its origin and character". This liability is limited by the requirement, under Draft Art 9 of the same Rules, that a given obligation binds the organisation at the time the act occurred. In some cases, such as those concerning human rights, the relevant obligations contained in multilateral treaties and customary law are not addressed to international organisations, but only States and as a result the trustee will not bear liability for any subsequent breach of a human rights obligation.

${ }^{190}$ The uncontested practice with respect to UN-mandated peacekeeping and peace enforcement missions is that unlawful acts committed by national contingents participating in Chapter VII action that are not constituted under a UN Force give rise to member State liability. On the other hand, the UN is liable for unlawful acts committed by national contingents that operate under a UN Force. See ILC Second Report on Responsibility of International Organisations, UN Doc A/CN.4/541 (2 April 2004), pp 13-23. However, even in those cases where the national contingent is under a UN Force but the retention of disciplinary power and criminal jurisdiction is vested exclusively in the contributing State, any unlawful act committed as a result engages the liability of the State and not the Organisation. See Attorney-General v Nissan [1969] 1 AER 639, p 646.
} 
personal State responsibility, as opposed to the sole responsibility of the trust entity, involves those cases where the contribution of the donor causes harm to third parties. We have already demonstrated examples stemming from the implementation of disbursements (e.g. knowingly constructing a faulty power plant).

Equally, however, there is little justification in the donor simply providing money for a trust whose functions and operations he either does not care about, or in respect of which he foresees that they are likely to breed widespread corruption, sustain authoritarian rule, distort regional competition, or directly injure neighbouring States in some other way. ${ }^{191}$ What is the likely legal basis for the exclusion of donor liability in these cases, given that the act of contribution is directly linked to the perpetration of unlawful acts? The only justification offered by the donors as a matter of exculpation seems to be the intergovernmental trust model itself, ${ }^{192}$ but this is exactly the basis of the problem and absent a convincing and unambiguous customary rule it certainly cannot constitute the solution to our conundrum. It is evident that irrespective of the answer to the aforementioned problems, the trust relationship cannot shield the donor from injury caused to third States as a result of operations directly attributed to the donor's contribution, given that the limitation clause does not operate against third parties to the trust agreement. ${ }^{193}$

I am similarly dissuaded by the argument that the donor should bear no liability in cases where his contribution sows a range of foreseen, but not directly intentional, calamities in the territory of the target State, or in respect of its interests. Certainly, were the donor was able to demonstrate that the injury was unforeseeable or that every care was taken in consultation with the trustee to avoid the injury, all of which was conducted and undertaken in good faith with the additional consent of the target State, the donor's potential liability would be significantly mitigated and most probably erased. It is, therefore, prudent for prospective donors to undertake serious due diligence exercises prior to making a pledge or contribution to a trust fund, although in practice it is unlikely, or at least rare, that the target State will make claims directly against a donor. In theory, if one admits that a particular trust fund set up to assist developing States was poorly monitored and helped an already authoritarian regime to purchase arms and stifle democracy, a succeeding democratic government should be able to claim damages against the donors for directly contributing to the denial of internal self-determination and the breeding of corruption. It is, nonetheless, evident that the issues explored and raised in this section are by no means clear, or amenable to straightforward answers. This discussion is aided by reference to a particular case study in the next section which I believe constitutes a clear example of an abusive trust that should not benefit from any of the customary traits of the intergovernmental trust paradigm. There is no doubt that in practice the vast majority of beneficiaries will be disinclined from claiming damages against the donors under the circumstances described in this section out of fear that the funding may cease altogether.

\footnotetext{
${ }^{191}$ The ICJ in Albania v UK (Corfu Channel case), Merits, (1949) ICJ Rep 4, pp 22-23, although discussing the liability of a State in respect of omissions, held that Albanian liability was established where it knew, or must have known of the presence of mines in its territorial waters and yet offered no warning. Mutatis mutantis it is arguable that failure to avert an injurious act where the donor knew or should have known of it occurring under a set of particular circumstances gives rise to liability.

${ }^{192}$ Instrument Establishing the Prototype Carbon Fund, s 12.4.

${ }^{193}$ This is even more so since under the emerging customary law of intergovernmental trust funds the assets of the trust are only in the legal (or trust) ownership of the trustee. In reality, therefore, the contributing States actually own those assets.
} 


\section{Abusive Trusts: The Fine Line between International Trust, International Agency and Partnership Arrangements}

The relative underdevelopment of international trust law struggles to draw the boundaries between agency and the international sui generis trust relationship. In national legal systems statute law and the courts clearly establish this boundary, which is operable irrespective of any self-characterisation of the relevant relationship by the settlors as to its legal form, on the basis of their mutual agreement. In international law, the contributors may wish to designate the respective vehicle as a trust fund in order to avoid personal liability, or to avoid the subjection of their contributions to the securities law of the lex forum, as well as the imposition of domestic taxation, inter alia, despite the fact that the relationship established leaves no room for the trustee to reach independent judgment as to his fiduciary duties towards the trust's beneficiaries. The situation becomes more complicated and somewhat untenable where the instrument of the purported trust vehicle makes no claim to distribute assets or revenues to third party beneficiaries, at least directly, but only to the contributors themselves.

This is precisely the case with the Prototype Carbon Fund (PCF), which was set up under an initiative of the World Bank in order to attract companies and governments from developed States with a view to offsetting their carbon emissions through the establishment of carbon-free projects in the developing world in the form of earned credits. ${ }^{194}$ The idea was truly innovative and the trust vehicle contemplated was eventually comprised of a three-tier governance structure, at the apex of which stand two equally powerful bodies, the Participants' Meeting and the Participants' Committee. The Meeting possesses the function of an assembly, save that it has the power to review the operations of the Fund and that of existing projects and provide the trustee with "general policy and strategic guidance" on all the operations of the Fund, including the budget. ${ }^{195}$ In short, the Meeting possess absolute decision-making authority to which the trustee is obliged to adhere. From its very nature this allocation of power in respect of the PCF is wholly antithetical to the World Bank's general trustee functions. The Participants' Committee is but a different emanation of the Meeting, in that it is mandated with a more practical role that involves taking the day-to-day decisions and implementing the policy and guidance of the Meeting on the ground. ${ }^{196}$ Unlike the Meeting that is comprised of representatives of all contributing participants, involving State parties to the Kyoto Protocol, ${ }^{197}$ but more significantly private enterprises, the Committee comprises only seven participants, four of which are members of public sector participants, whereas the remaining three are derived from the private sector. ${ }^{198}$ This structure conforms to a relative equality of the parties, which is further reinforced by the voting scheme that introduces the rule of one vote for each US dollar of contribution to the Fund in respect of the Meeting. ${ }^{199}$ The rule of one vote per participant applies with regard to the Committee. ${ }^{200} \mathrm{On}$ the other hand, the trustee shall hold the assets in trust and is endowed with authority to manage the assets, as well as conclude participation agreements and enter into contracts that promote the objectives of the Fund. ${ }^{201}$ The trustee is moreover authorised to invest the assets

\footnotetext{
${ }^{194}$ See S Smyth, The Prototype Carbon Fund: A New Departure in International Trusts and Securities Law, (2005) 5 Sustainable Development L \& Policy 28, p 29.

${ }_{195}$ Prototype Carbon Fund Instrument, Art V(1).

196 Art VI, id.

${ }^{197}$ Kyoto Protocol, supra note 188.

198 PCF Instrument, Art VI(1)(c).

${ }^{199}$ Id, Art V(4).

${ }^{200} \mathrm{Id}$, Art VI(2).

${ }^{201}$ Id, Art VIII(1)(a)-(e).
} 
of the Fund "in such manner as [he] may decide ... as are authorised investments for other trust fund assets maintained by [the World Bank Group]". ${ }^{202}$

It is clear from the very objective of the Prototype Carbon Fund that it involves a bilateral, rather than a trilateral, relationship. Typical trust funds comprise a settlor (or donor), a trustee and third-party beneficiaries, whereas the Carbon Fund lacks such beneficiaries, given that the participating States infuse money into the Fund with a view to gaining future emission credits. Certainly, an argument can be made that the Host Countries and their peoples benefit from this scheme through the projects set up therein by the participants. However, this hardly qualifies them as direct beneficiaries of the Carbon Fund. Moreover, the IBRD as trustee to the Carbon Fund is not empowered to take any decisions outside the parameters set by the Participants' Meeting. The Instrument devotes a very long provision to the trustee's powers, ${ }^{203}$ but these are of a purely administrative nature and do not go beyond managing and implementing the day-to-day administrative functions of the Fund. Furthermore, the authority of the trustee in respect of certain functions is severely curtailed by the express terms of the Instrument. ${ }^{204}$ The limitation of the trustee's powers to make decisions as to the allocation process and its statutory inability to take action on the basis of its own judgment in the best interests of a predefined class of beneficiaries renders the status of the Carbon Fund somewhat conspicuous. ${ }^{205}$ Although the limitation of the trustee's powers may be justified by reference to other trusts whereby the trustee was found to possess no decision making powers, in neither of these trusts did the donors expect to gain a financial or other direct benefit from the operations of the trust. As a result, it was initially queried even within the Bank itself whether the participants' financial contributions thereto amounted in fact to securities, in which case the Fund was not to be viewed as a trust and the Bank's role would best be construed as that of a managing agent.

The crucial question therefore was whether or not the participants' contribution amounted to a security under US federal law, which involves an investment transaction or scheme from which the investor is led to expect possible profits from the actions of the promoter or third parties. ${ }^{206}$ Given that the participants expect to gain beneficial interests from the operation of the trust these would necessarily assume the character of securities under the Howie test as this is applicable to business trusts. ${ }^{207}$ Neither the Bank nor the participants wished to have their contributions subjected to US securities law, each for its own personal reasons, but certainly none wanted to wait to go through the time consuming process of registering with the US Securities and Exchange Commission (SEC). As a result, the Bank decided to proceed with the operations of the Fund, particularly the worldwide attraction of participants, by adhering to the "private placement exemption" of the 1933 US Securities Exchange Act, ${ }^{208}$ whereby transactions not involving a public offering are exempt from the registration obligations warranted under the Act. The application of this exemption is possible only where the offer is made to a pre-determined body of offerees with access to all the relevant information and who are, moreover, in a capacity to demand and interpret said information. ${ }^{209}$ Given that any public advertising involves a public offering, ${ }^{210}$ it was hard to

\footnotetext{
${ }^{202}$ Id, Art VIII(1)(f).

${ }^{203}$ Id, Art VIII(1).

${ }^{204}$ Id, Art VIII(6).

205 This author is certainly not advocating the existence of a customary right of a particular set of implied powers inherent in the trustee's functions. The existence, or lack thereof, of implied powers is necessarily and always dependent on the instrument of appointment.

${ }^{206}$ See SEC v Howie, 328 U.S. 293 (1946), pp 298-99.

${ }^{207}$ SEC v Banner Fund International, 211 F.3d 602 (DC Cir., 2000).

${ }^{208} 15$ U.S.C. $\$ 77(\mathrm{~d})(2)$.

${ }^{209}$ SEC v Ralston Purina Co, 346 U.S. 119.

${ }^{210}$ See Koehler v Pulvers, 614 F Supp 829 (SD Cal, 1985).
} 
justify the exemption vis-à-vis the Prototype Carbon Fund for which the World Bank had initially launched a global campaign to attract participants. This campaign included the hosting of conferences, advertisement and an aggressive marketing effort. Consequently, the Bank was forced to amend its marketing strategy and limit all actions that may have otherwise been interpreted as constituting a public offering, even going as far as dismantling its public website that was subsequently replaced by a new encrypted one accessible only to the participants. ${ }^{211}$ Smyth is of the opinion that the Prototype Carbon Fund, despite its agency or partnership-looking legal structure, should be viewed as a trust fund regulated under international law on the basis that the trustee is not a for-profit institution and many participants are sovereign States. ${ }^{212}$ This is probably not, however, the best criterion for ascertaining the legal position of the Fund. The Fund should be assessed on the basis of its function, the legal personality of the trustee and its participants, as well as the position of the countries where the offsetting credits are purchased. Furthermore, the liabilities of the Fund should be assessed objectively in accordance with general international law. If the ultimate nature of the Fund's operations are jure gestionis, and solely for the commercial benefit of the participants, its purported public international character cannot seriously be justified. The jure imperii character of the Fund, on the other hand, is reinforced by the international legal personality of the trustee and its State parties and the environmental objective involved.

Finally, and this is perhaps the most important observation, even if the States in which the Fund operates determine objectively that it is not a trust but an agency arrangement and that the participants' contributions are best described as securities, they may, nonetheless, consent to it being self-proclaimed a trust under international law and governed under the particular customary law of intergovernmental trusts. They may justify turning a blind eye by reference to the international legal personality of the trustee under whose trusteeship the Fund is registered and it may also transpire that the trust vehicle best accommodates the interests of the States concerned by reason of its environmental incentives and the benefits accruing to their corporations. Overall, however, this author is not happy with conferring trust status to the PCF for an additional reason. Section 8.1(m) of the Fund's Instrument astonishingly does not preclude the IBRD:

from acting for its own account and from entering into or being interested in any contract or transaction with any person, including, but not limited to any participant [etc] with the same rights as it would have had if it were not acting as the Trustee, and the IBRD need not account for any profit therefrom.

This function is no doubt incompatible with the function of trustee and gives rise to such significant conflicts of interest that raises doubts as to whether the international law of trusts should apply at all in this case. It, moreover, sits uncomfortably with the longstanding position in the common law whereby the trustee must not compete with those persons to whom he owes a duty, or to derive any profit from his role as such or otherwise be seen to derive profit. ${ }^{213}$ The implication stemming from this observation is that were the trustee to acquire a trust asset, this transaction would generally be voidable even if the trust bears no loss. ${ }^{214}$ Overall, in my opinion the PCF constitutes an abuse of the trusteeship process envisaged under the international law of trusts and the participation of both the donors and the trustee therein clearly gives rise to their personal liability.

\footnotetext{
${ }^{211}$ Smyth, supra note 194 , p 33.

${ }^{212} \mathrm{Id}, \mathrm{p} 32-33$.

${ }^{213}$ See M Lupoi, Trusts: A Comparative Study (Cambridge UP, 2000), p 168.

${ }^{214}$ Aberdeen Railway v Blaikie Brothers [1854] 1 Macq 461, per Lord Cranworth LC, p 471.
} 


\section{Conclusion}

I am convinced that the intergovernmental trust model analysed in this article is of a sui generis nature. Its fundamental characteristics are the reliance on agreement between trustee and donor where its purpose is to confer a benefit on a third party, whether pre-defined or not. If the purpose of the trust is to confer financial or other benefits to the donor or the trustee through the trust's assets, the privileges accruing to such trusts should generally be viewed as being inapplicable for the simple reason that it would constitute a self-contract. It is just and fair that the trust property should enjoy privileges and immunities in the hands of the trustee and that the donors limit their liability against third parties, because of the benevolent and charitable character of trusts and the lack of personal interest in the person of the donor. Any imbalance in this relationship, particularly as regards situations where the donor does accumulate financial gains or causes an unlawful act through his contribution, the privileges of the trust should not operate to shield him from liability. The same is true in respect of the trustee.

Although it is true that prospective or designated beneficiaries possess few, if any, remedies against the trust entity or the trustee, one of the overarching tenets of intergovernmental trust funds is the principle of local ownership. This is meant to empower the government and civil society of the target (beneficiary) State with such capacity as to implement the trust's on-the-ground project and take charge of the realisation of its objectives. At the very least, trustees must make available quasi-judicial mechanisms, subject to their institutional law, by which to allow civil society to report any wrongdoings. The amounts of financial resources injected into many trust funds are such that they generate a procurement scramble and a general reluctance on recipient States to question the practices of implementing agents. There is always a real danger that instead of delivering a viable and useful service, some implementing agents are delivering quite the opposite. Trustees must give a voice to civil society, given that the local courts of a distressed developing country are hardly an adequate forum for addressing these issues.

This author is generally weary about characterising ambiguous actions at the international level as subject to customary law. Nonetheless, it is hoped that the reader is convinced that on account of the overwhelming practice of States in entering into trust agreements, trusts headquarters agreements, unilateral donations, as well as from their general stance as donors or recipients that certain functions of the trust model are beyond doubt part of a globally consistent and coherent practice. This practice is, moreover, confirmed by the practice of those international organisations acting as trustees through their institutional law. These principles, which have been analysed extensively throughout this article, are: a) trusts are based on agreement, whether formal or informal; b) there is no requirement that the trust possess any kind of domestic or international legal personality; c) the privileges and immunities of the trustee cover also the assets of the trust; d) no personal liabilities arise from the operation of the trust for the donors and the trustee, unless they have personally caused the infliction of an unlawful act; e) the assets of the trust are in the ownership of the trustee; f) none of the above applies where the aim of the trust relationship is to materially benefit the donors or the trustee, over and above any benefit to third parties. 
